\title{
Naturalisation and Investments in Children's Human Capital: Evidence from a Natural Experiment
}

\author{
Friederike von Haaren-Giebel* \\ Leibniz Universität Hannover
}

This version: 18 February 2016

\begin{abstract}
This paper assesses educational attainment of immigrant children, in particular evaluating whether naturalised parents invest more in their children's human capital than nonnaturalised parents. Findings of the literature indicate that citizenship is associated with lower return migration probability. Since the returns to investments in (country-specific) human capital increase with the duration of residence, naturalised parents may have more incentives to invest in the educational success of their children. I exploit a natural experiment that took place in Germany in the year 2000 that reduced the required years of residence for naturalisation from 15 to 8 and therefore exogenously increased naturalisation. Multivariate estimations (based on the German Socio-Economic Panel) show a positive and significant correlation between parents' citizenship status and their children's educational attainment. Results of difference-in-differences and instrumental variable models are also positive but not significant.
\end{abstract}

JEL: classification: J15; J24; I24

Keywords: citizenship; integration; education; SOEP

\footnotetext{
* Institut für Arbeitsökonomik, Leibniz Universität Hannover, Königsworther Platz 1, 30167 Hannover, Germany
} 


\section{Introduction}

One third of the German population younger than 20 are children of immigrants either born in Germany or who migrated to Germany with their parents (Statistisches Bundesamt 2014). Although raised in Germany, the children of immigrants often lag behind natives with respect to educational outcomes (Dustmann et al. 2012, Meurs, Puhani and von Haaren 2016). Since education is essential for future labour market success, it is important to understand what determines educational decisions in order to choose policies for enhancing labour market integration of immigrants.

In this paper, I examine a controversial policy measure that aimed to improve immigrants' integration, namely facilitating naturalisation. In particular, I analyse whether naturalised parents invest more in their children's human capital. Descriptive statistics based on the German Socio-Economic Panel (SOEP) show that the share of immigrant children on the high education track (i.e. going to the Gymnasium, having a university entrance qualification or studying) is $21 \%$ among children whose parents are not naturalised and $35 \%$ among those whose parents are naturalised. One explanation for this discrepancy in educational attainment may be that naturalisation ensures residence status or may induce parents to stay longer in Germany and affect return migration decisions (as also suggested in a different context by Avitabile et al. 2013). Since the returns on investments in (country-specific) human capital increase with the (expected) duration of residence, naturalised parents may thus have more incentives to support the educational success of their children. This hypothesis is in accordance with the finding that uncertainty related to return migration can significantly affect immigrants' human capital investments negatively (Dustmann 1999). Descriptive statistics support the assumed relation between naturalisation and planned duration of residence in Germany: while $82 \%$ of naturalised first-generation immigrants want to stay in Germany forever, only $48 \%$ of non-naturalised immigrants want to.

To estimate the effect of parent's naturalisation decisions on their children's educational attainment, I exploit a natural experiment that took place in Germany in the year 2000. Since 1993, immigrants aged 23 or older had had a legal claim to naturalisation after 15 years of residence in Germany, and immigrants aged between 16 and 22 after 8 years of residence. On 1 January 2000, a reform of the citizenship law came into effect that reduced the required 
years of residence from 15 to 8 for all immigrants, independent of their age. Immigrants with a duration of residence between 8 and 14 years and aged at least 23 were thus treated by the reform. Immigrants with a duration of residence of at least 15 years were not affected and thus serve as a control group. Using data of the German Socio-Economic Panel (SOEP), information on treatment and control groups is available before and after the reform. Therefore, I can apply the difference-in-differences (DiD) design. For the period of 1994 to 2006, I analyse educational attainment of immigrant children aged 11 to 23 depending on their parents' citizenship and treatment status.

Some other recent studies examine the link between naturalisation (or citizenship status) and education, labour market outcomes and social integration indicators using a similar research design. The paper which is perhaps most related to my study analyses the effect of citizenship status on human capital acquisition among immigrant children in Germany (Felfe and Saurer 2014). Using the introduction of birthright citizenship in 2000, they identify positive effects of birthright citizenship on educational participation. They thus study the effect of children's own citizenship status that is independent of their parents' citizenship status. In contrast, my paper examines whether parents' citizenship status has an effect on children's education outcomes. ${ }^{1}$ My study also has some similarities to Sajons (2015) and Avitabile et al. (2013), who analyse the effect of the introduction of birthright citizenship for children born in Germany to non-German-citizen parents on parental integration outcomes. Sajons' (2015) results based on a regression discontinuity design indicate that granting citizenship to immigrant children induces families to stay in Germany and decreases family outmigration rates. Applying the DiD methodology, Avitable et al. (2013) find positive effects of children's citizenship on parents' probability of interacting with native Germans and of using the German language. They conclude that migration rules can also indirectly affect individuals who were not directly targeted by these rules. I analyse this question from the reverse perspective, namely whether a change of the parents' legal status also affects children's outcomes. Moreover, my paper is related to Gathmann and Keller (2014), as they also exploit the reduction in the residency requirements for naturalisation for adult

\footnotetext{
${ }^{1}$ Since in my paper the youngest children were born in 1995, the sample members are not affected by the introduction of birthright citizenship for children born after 1999, which also came into effect in 2000 (see also section 2).
} 
immigrants in Germany. They find positive effects on labour market outcomes for women but only a few small effects for men. ${ }^{2}$

I use a mix of methods to analyse whether naturalised parents invest more in their children's human capital, in which being on the high-education track serves as a proxy for investments in human capital. Firstly, I estimate linear probability models controlling for several personal and parents' background characteristics. Secondly, I apply a DiD design. Since the treatment group includes individuals who potentially naturalise, this strategy identifies the intentionto-treat effect, the effect of being eligible to naturalise. And thirdly, I use the interaction of treatment group and post-reform period to instrument parent's naturalisation status. In contrast to the $\mathrm{DiD}$ design, this approach incorporates whether individuals actually react to the reform.

While the results of the linear probability models show a strong and significant correlation between parent's naturalisation status and the probability of being on the high education track (+ 15 percentage points), results from models taking unobserved heterogeneity into account yield no significant effect of parents' naturalisation status on children's educational outcomes. The DiD yields a point estimate of 0.084 with a standard error of 0.088 . On the one hand, the small sample size may lead to imprecise and insignificant estimates. On the other hand, the results may suggest that naturalisation has no effect on children's education and that naturalised parents are a positively self-selected group.

To shed some light on possible channels that explain why children of naturalised parents are better educated, I estimate on the one hand the models with different dependent variables, and on the other hand those with alternative explanatory variables for the parents' naturalisation status, namely whether parents (i) plan to naturalise within the following two years, (ii) wish to stay forever or (iii) for more than 10 years in Germany. For a subgroup of 17-year-old individuals, it is possible to have a closer look at parental investments in children's human capital, i.e. receiving private paid tutoring and whether parents are strongly concerned about their children's school achievement. Furthermore, I analyse whether children of naturalised parents have different perceptions on career orientation.

\footnotetext{
${ }^{2}$ Furthermore, several studies examine the educational attainment of second generation immigrants, see for example Meurs, Puhani and Von Haaren (2016), Krause, Rinne and Schüller (2014), Schüller (2015), Gang and Zimmermann (2000) or Riphahn (2003).
} 
The paper is organised as follows: the next section describes the German naturalisation law and the reform. Section 3 explains the data and the estimation strategy. Section 4 illustrates descriptive statistics and presents the results. Section 5 discusses possible channels of naturalisation and section 6 concludes.

\section{Institutional Setting}

This paper uses a reform of the German naturalisation law that came into effect in the year 2000. Since 1991, immigrants aged 23 or older had had a claim on principal to naturalisation after 15 years of residence in Germany (they "should usually be" naturalised), while immigrants aged between 16 and 22 had had a claim after 8 years. In 1993, this claim on principle was transformed into a legal claim (von Münch 2007). This meant that immigrants who fulfilled the naturalisation requirements and filed an application "should be" naturalised. In addition to the obligatory duration of residence, further naturalisation requirements were impunity, having independent means of securing a living without resorting to welfare payments (including for family members entitled to maintenance) and giving up former citizenship (for an overview of regulations see also Table A 1). The reform of the year 2000 reduced the required years of residence from 15 to 8 for all immigrants aged at least 16. Consequently, immigrants with a duration of residence between 8 and 14 years and aged at least 23 received the right to naturalise and were thus directly affected by the reform (see also Figure 1). This is the essential change for the identification strategy that defines treatment and control group.

- Insert Figure 1 here -

However, the reform involved several additional changes. On the one hand, the acceptance of multiple citizenships increased with the reform, because immigrants from EU member states have been allowed to keep their original citizenship after naturalisation since 2000 . However, immigrants from non-EU member states generally still have to give up their original citizenship after having acquired German citizenship. Though, some exceptions exist. ${ }^{3}$ On the other hand, the reform reduced the possibility of holding multiple citizenship,

\footnotetext{
${ }^{3}$ For example, giving up the original citizenship is not mandatory if the conditions are deplorable (e.g. paying very high fees), if it is not possible to give up the citizenship or if the immigrant is a recognised refugee (Bundesregierung n.d. a, von Münch 2007).
} 
because it closed a "loophole" in the law. Generally, German citizens who acquire foreign citizenship lose their German citizenship. However, according to the so-called "domestic clause" ("Inlandsklausel") of the former version of the citizenship law, citizens who live in Germany were exempted from this rule. In practice, this clause constituted a possibility for acquiring dual citizenship and was increasingly used in the late 1990s, especially by Turkish immigrants, as it was promoted by the Turkish authorities (Bundestagsdrucksache 16/9654, Frankfurter Allgemeine Zeitung 2005). ${ }^{4}$ After immigrants naturalised in Germany and gave up their Turkish citizenship, for example, they re-acquired their original citizenship by naturalisation in their country of origin. After the reform of the law in the year 2000, the domestic clause was omitted. This means that the reform may be regarded as tightening the restrictions for dual citizenship for Turkish immigrants. Nevertheless, the reform facilitated naturalisation through the reduction of the required years of residence also for immigrants from Turkey. Figure A 1 illustrates that naturalisation rates of immigrants from Turkey increased even more than those of immigrants from all other countries.

A further change in law that may be regarded as an aggravating factor is the requirement of language proficiency. Although it is not a direct requirement, insufficient language skills are an exclusion criterion for naturalisation ( $\$ 86$ AuslG). The law, however, is neither clear about the level of language proficiency nor about the question of how language knowledge should be proved (Hailbronner and Renner 2005). Confession to the free democratic order of the German constitution is a further new element, although this does not increase the effort for naturalisation. Moreover, naturalisation fees for adults increased with the reform in 2000 from 51 to 255 Euro (Von Münch 2007). All in all, the reform of the citizenship law is regarded as a facilitating move, especially because the required duration of residence was decreased (Worbs 2008, von Münch 2007).

In addition to the reform of the citizenship law, birthright citizenship for children born after 1999 was also introduced in the year 2000. Since the sample analysed contains children born between 1971 and 1995, individuals were not affected by the introduction of birthright citizenship but only by the reduction of the required duration of residence through their parents. Therefore, this paper examines the effect of parents' citizenship status on investments in children's human capital, which is different from Felfe and Saurer (2014) and

\footnotetext{
${ }^{4}$ However, the share of immigrants from Turkey with dual citizenship was nevertheless lower than that of immigrants from all other countries ( $10 \%$ versus $24 \%$ in 2000; this information is not available in the data before the year 2000).
} 
Sajons and Clots-Figueras (2014), who analyse the effect of birthright citizenship (children's citizenship status) on children's educational outcomes. Although there was a transition rule for children born between 1990 and 1999 (they could also acquire German citizenship if the conditions for birthright citizenship were fulfilled and parents filed an application before $31 / 12 / 2000$ ), only very few made use of this transition rule (Felfe and Saurer 2014; 7\% of all naturalisations between 2000 and 2003 were based on this transition rule, Bundesregierung 2005).

Parallel to the claim of naturalisation, immigrants could always (even before 1991) file an application without meeting all requirements. Although these immigrants have no claim to naturalisation, they can be naturalised according to the authority's discretion ("Ermessenseinbürgerung") if they meet several minimum requirements defined in administrative regulations (Bundesregierung n.d. b). These regulations are mainly applied for spouses and under-age children of Germans or naturalised immigrants. For them, the required duration of residence is only four and three years respectively (see also Table A 1). Naturalisation according to the authority's discretion for other individuals also usually requires 8 years of residence in Germany (10 years before the reform). However, the usual minimum duration may be shorter if special public interest exists (e.g. for athletes, von Münch 2007).

The reasons for the reform of the citizenship law in the year 2000 were that politicians hoped that the new regulation would foster integration (Gnielinski 1999). Furthermore, in the 1990s, many permanent immigrants who had lived in Germany for a long time and were economically and socially integrated were still foreigners, and thus neither politically nor judicially integrated. The reform aimed to reduce this disproportion (Bundesregierung 1995).

After 2005, several further changes followed: since 2005 it has been possible to reduce the required minimum duration of residence in Germany by participation in an integration course. In 2007, knowledge of legal and social regulations and of living conditions in Germany was introduced as an additional naturalisation requirement. In order to generate an instrument that proves this knowledge, a naturalisation test was implemented in 2008. Since this additional requirement may increase the effort required for naturalisation, the observation period is restricted to 2006 . 


\section{Empirical Approach}

\subsection{Data}

I use data of the $\mathrm{SOEP}^{5}$, which contains relevant information for identifying treatment and control groups. The panel exists since 1984 and contains representative information of nearly 12,000 households. Due to oversampling of immigrants, it is the largest survey of immigrants in Germany (www.diw.de, Wagner et al. 2007). ${ }^{6}$

Since parents' investments in children's' human capital are not directly observable, I use children's educational participation, namely being on the high education track, as an approximation. More precisely, children who go to grammar school (Gymnasium), who have achieved the university entrance qualification or who are studying are defined as being on the high education track. Educational attainment is a usual approximation in the literature for investments in human capital (e.g. Mitrut and Wolff 2014, Becker 1962). The explanatory variable of interest is the parents' naturalisation status or their treatment status. To define naturalised individuals, I make use of the panel structure of the data. Individuals who once had foreign nationality and gained German citizenship later are defined as naturalised. Non-naturalised individuals are individuals with foreign citizenship living in Germany. ${ }^{7}$ The parents' treatment status is defined according to the parents' duration of residence in Germany. Children whose parents were affected by the reform (duration of residence in Germany between 8 and 14 years) constitute the treatment group, while children of parents with a longer duration of residence in Germany (15 years or more) form the control group, as these parents were not affected by the reform (see also Figure 2).

- Insert Figure 2 here-

\footnotetext{
${ }^{5}$ Socio-Economic Panel (SOEP), data for years 1994-2006, version 29, SOEP 2013, doi: 10.5684/soep.v29

${ }^{6}$ However, the numbers of observations in the treatment group by year are small (see Table 1). Nevertheless, it is not possible to use other data sources such as the German Microcensus because although information on German or foreign citizenship is available in all years, foreign-born and naturalised individuals can only be identified since 2005. Using the information on the year of migration and year of naturalisation, it would be possible to identify treatment and control groups retrospectively, but since retrospective information on children's educational outcomes are not available, there is no information on the dependent variable for the pre-reform period.

${ }^{7}$ Since 2002, individuals are asked directly whether they are naturalised and if so, in which year. This generates additional information only for individuals who were naturalised before they entered the survey. However, since no retrospective information on their children's education participation is available, this additional information cannot be used.
} 
To account for cultural differences, immigrants are categorised according to their country of origin, which is defined either according to the child's country of birth, or if the child was born in Germany, according to the mother's country of birth or according to the father's country of birth if information on the mother's country of birth is missing. Due to small sample sizes, I group together immigrants from Western European countries, Eastern European countries, Turkey and other countries. ${ }^{8}$

The sample is restricted to children aged 11 to 23 . Before the age of 11 , most of the children are in primary school, with no information on tracking thus available for them. ${ }^{9}$ The upper age limit has to be as high as possible to increase the sample size, but must not be too high so that parents are still able to influence their children's educational decisions. The sample contains both children who live with their parents in one household and adolescents who have already left their parents' home. ${ }^{10}$ At the age of $23,52 \%$ of individuals are living together with their parents in the overall population. In the sample analysed, $95 \%$ of the individuals aged 11 to 23 are living with their parents in one household.

The observation period starts in 1994 and ends in 2006, because a legal claim of naturalisation has only existed since mid-1993, and in 2007 and 2008, naturalisation requirements and regulations changed considerably again (see section 2). Furthermore, the sample only contains children of foreign-born parents; the children themselves may have been born abroad and migrated together with their parents to Germany $(18 \%)$ or were born in Germany (82\%). Children of non-naturalised parents do not have German citizenship, while most children of naturalised parents also have German citizenship (87\%), as they often also acquire German citizenship when their parents are naturalised. The sample analysed contains 3,459 observations, which is equivalent to 942 individuals. 299 individual-year observations belong to the treatment group and 3,160 to the control group (Table 1). Since

\footnotetext{
${ }^{8}$ The group of "other countries" mainly comprises immigrants from the Near and Middle East.

${ }^{9}$ Since tracking age varies according to federal state between grade four and six, the number of observations in the age groups of 11 and 12-year-olds are smaller. However, the share of children on the high education track in these age groups is similar to the share of 13-year-olds. Furthermore, tracking age changed in some states over time. Children who are still in primary school are not included in the sample.

${ }^{10}$ These immigrants are tracked by their original household number. Up to the age of 16 almost $100 \%$ of individuals live together with their parents, afterwards the share decreases. Although individuals who still live with their parents in one household at the age of 20 (83\%) may be self-selected, it is not clear whether this is a positive or negative selection with respect to high education track attendance. On the one hand, it might be a positive selection because individuals who are working might be more likely to move away, on the other hand, it might be a negative selection if individuals who start studying are more likely to move away.
} 
the numbers of observations for the treatment and control group by year are very small, I pool the years 1994 to 1999 (pre-reform period) and 2000 to 2006 (post-reform period).

- Insert Table 1 here -

\subsubsection{Estimation Strategy}

In a first step, I estimate linear probability models (LPM) according to the following equation in order to find out whether the parents' naturalisation status correlates with the probability of being on the high education track, also controlling for demographic characteristics.

$$
Y_{i}=\beta_{0}+\beta_{1} p_{-} \text {natu }_{i}+\boldsymbol{\beta} \mathbf{x}_{i}+u_{i}
$$

The explanatory variable of interest is the parents' naturalisation status ( $\left.p \_n a t u\right)$, which is one if parents of individual $i$ are naturalised and zero for all individuals with first-generation parents with foreign citizenship. As control variables, I include dummy variables for the immigrants' origin, age, gender, parent's educational background, number of siblings as well as dummy variables for the year of observation to control for cohort and time effects. ${ }^{11}$

However, the parents' naturalisation status is probably endogenous, because it may be related to unobservable characteristics that are also correlated with the children's education track. Therefore, the identification strategy relies on exploiting the natural experiment that took place in the year 2000. I estimate difference-in-differences (hereafter DiD) as well as instrumental variable (hereafter IV) models.

While the reform affected immigrants with a duration of residence between 8 and 14 years, aged at least 23, immigrants with a longer duration of residence were not affected. ${ }^{12}$ Consequently, children belong to the treatment group when their parents are aged at least 23 and have lived between 8 and 14 years in Germany. Before the change in law, these immigrants had no legal claim to naturalisation. Children whose parents have lived in Germany for at least 15 years and are aged at least 23 belong to the control group, as they

\footnotetext{
${ }^{11}$ I decided to include the parents' educational background instead of the parents' income for two reasons: firstly, although parental income is likely to influence children's educational outcomes, parental educational background is assumed to have a larger effect, especially among the immigrant population. Secondly, there are too many missing values for parental income.

${ }^{12}$ Immigrants with a duration of residence shorter than 8 years were not affected either, and thus also a potential control group. However, I do not use this group as a control group, firstly because it includes recent immigrants, who differ in several ways from immigrants with a longer duration of residence, and secondly because this group may contain immigrants who were naturalised before the generally required duration of residence due to the authority's discretion, e.g. because they are married to a German.
} 
already had a legal claim of naturalisation before the reform. Since the data provides information on treatment and control groups before and after the reform, the DiD method can be applied (second step). I estimate the following equation:

$$
Y_{i}=\beta_{0}+\beta_{1} T G_{i} * \text { after }_{i}+\beta_{2} T G_{i}+\beta_{3} a_{f t e r}+\boldsymbol{\beta} \mathbf{x}_{i}+u_{i},
$$

where $T G$ is a dummy variable that indicates whether child $i$ belongs to the treatment group, after is a dummy variable for the post-reform period and $T G^{*}$ after is the interaction of these two variables, the DiD estimator. Vector $\mathbf{x}$ includes the same control variables as the LPM. As the endogenous explanatory variable (parents' naturalisation status) is substituted by exogenous variables (dummy variables for treatment group, post-reform period and the interaction of both variables), the model can be considered as a reduced form model. This approach identifies an intention-to-treat (ITT) effect, since the parents' naturalisation status is only implicitly considered. The change in law, however, does not solely determine enrolment in naturalisation. Although eligible, not all individuals will apply for German citizenship; this means that there is noncompliance. Therefore, the average effect of the treatment on the treated (ATT) is not identified in general, but rather the average effect of offering facilitating naturalisation on the children's educational outcome of eligible parents (ITT effect). Since this effect comprises the zero effect for non-compliers and the returns to naturalisation for those who change their status due to the reform, the ITT is smaller than the ATT (Blundell and Costa Dias 2009). The advantage of this strategy, however, is that it controls for the endogenous decision to naturalise. ${ }^{13}$

In a third step, I estimate the effect of treatment on the treated using the interaction of treatment group and post-reform period as an instrument. This is the ITT divided by the difference in compliance rates between treatment and control groups, where the ITT is the reduced form effect of the instrument and the first stage is the compliance rate associated with this instrument (Angrist and Pischke 2008):

\footnotetext{
${ }^{13}$ An alternative estimation strategy would be a fuzzy regression discontinuity design (RDD) using years of residence for fathers and mothers as the assignment variable. In the period 2000 to 2006 , the probability of naturalisation increases after 8 years of residence. Since the sample size of individuals whose mother or father is just below or just above the cut-off is very small, it would be necessary to compare a more broadly defined group and to include a polynomial for years of residence to hold differences between individuals arriving earlier and later constant. However, the composition of immigrants may change over time, especially with respect to their origin. In the DiD design, treatment and control group are allowed to differ as long as these differences stay constant over time. From my point of view, this assumption is somewhat weaker than the RDD assumption, therefore I decided to apply the DiD design.
} 
$p_{-}$natu $_{i}=\pi_{0}+\pi_{1} T G_{i} *$ after $_{i}+\pi_{2} T G_{i}+\pi_{3}$ after $_{i}+\pi \mathbf{x}_{i}+\varepsilon_{i}$,

In this stage, I estimate whether the instrument (interaction of treatment group and postreform period $\left(\pi_{\mathrm{i}}\right)$ ) has a significant effect on the parent's naturalisation probability. The second stage (equation 2.4) estimates the instrumented effect of parents' naturalisation status on the children's probability of being on the high education track.

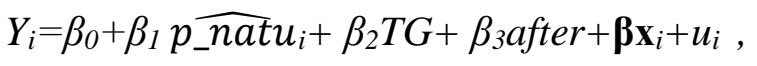

The IV approach estimates the average treatment effect (ATE) if individuals do not decide on treatment status, based on unobservable information. However, when individuals select into treatment and heterogeneous effects exist, then the IV approach does not identify ATE or ATT (Blundell and Costa Dias 2009). This is probably the case here, because individuals are usually aware of the benefits they gain from naturalisation. There are compliers, who naturalise because of the reduction in required years of residence, there are always-takers, who would have naturalised anyway (because of the possibility of naturalisation by the authority's discretion, “Ermessenseinbürgerung”) and there are never-takers, who do not naturalise although they have the right to do so. Therefore, the IV regression identifies the local average treatment effect (LATE) which is the ATT for compliers (Angrist et al. 1996). In this case this is the ATT for those who naturalise in the post-reform period because they benefited from the reform.

A valid instrument must be as good as randomly assigned and must not have a direct effect on the outcome variable (independence). This means that whether parents have lived between 8 and 14 years in Germany between 2000 and 2006 must not directly influence their children's education track attendance. The influence on the outcome variable is only allowed to be due to the effect of the instrument on the endogenous variable (exclusion restriction). In addition, the instrument must be correlated with the endogenous variable. Belonging to the treatment group must thus influence parents' naturalisation status in the post-reform period (significant effect in the first stage). Furthermore, I assume that the reform does not prevent anyone from naturalising (monotonicity or no defiers). 


\section{Results}

\subsection{Descriptive Statistics}

Figure 3 shows that the share of naturalised parents in the treatment group is zero in the prereform period and increases to $11 \%$ in the post-reform period. In the control group, the share of naturalised parents increases from $2 \%$ to $7 \%$, indicating that the general time trend is positive. As Table A 2 shows, there are no differences in the reaction to the reform between mothers and fathers overall. The share of children on the high education track increases among the treatment group from $26 \%$ to $31 \%$ and stays constant in the control group (21\%) (Figure 3 and Table 2).

- Insert Figure 3 here -

Descriptive results indicate that there is a positive time trend of naturalisations (Figure 3 and Figure A 1). Time effects do not bias the results, as long as treatment and control groups are both affected by these time trends. Ideally, information on treatment and control groups is available in several periods before and after the reform. In that case, it would be possible to check whether it is reasonable to assume that the common trend assumption is fulfilled. Due to the small sample size, it is not possible to illustrate the naturalisation shares by treatment and control group separately for each year here. ${ }^{14}$ It is however unlikely that there are time trends that affect only immigrants with a duration of residence between 8 and 14 years but do not affect immigrants who live in Germany for at least 15 years. Therefore, naturalisation rates of immigrants with a duration of residence between 8 and 14 years should develop similar to the naturalisation rates of immigrants with a duration of more than 14 years in absence of the reform. However, this may not be the case if there are compositional changes within each group over time, which are also related to the naturalisation probability. As long as there are no systematic compositional changes within each group over time, different characteristics of the treatment and control groups do not bias the results in the DiD approach. Table 2 shows characteristics of the treatment and control group in the pre- and post-reform period. Unfortunately, group characteristics do vary over time, especially with respect to immigrants' origin. Before the reform, the largest group of immigrants in the

\footnotetext{
${ }^{14}$ Ideally, I would illustrate the share of naturalised parents in the control and treatment groups for each year. If the explanatory variable of interest as well as the outcome variable and further explanatory variables develop parallel to one another before the reform, it would be reasonable to suppose that the common trend assumption holds.
} 
treatment group was of Eastern European origin (28\%), with this share even increasing to $60 \%$ in the post-reform period. In contrast to this, the share of immigrants from Eastern Europe decreased in the control group (from 24\% to 15\%). While in the pre-reform period, $26 \%$ of immigrants in the treatment group came from Western European countries, this share decreased to $7 \%$ in the post-reform period. The share in the control group also decreased over time (from $34 \%$ to $28 \%$ ). While the share of immigrants from Turkey decreased from $22 \%$ to $13 \%$ in the treatment group, it increased in the control group from $41 \%$ to $51 \%$. The share of immigrants from other countries remained similar in both groups and time periods. Furthermore, the parents' educational background changed in the treatment group. While the share of lowly and highly educated parents decreased, the share of medium educated parents increased in the treatment group. In the control group, the educational distribution stays nearly constant. The composition of the treatment group is probably more unstable than that of the control group, because of the small sample size of the treatment group. To control for these compositional changes, I include several explanatory variables, especially with respect to immigrants' origin and parental education background. Further potentially existing time trends such as changes in the educational system, are likely to affect treatment and control groups in the same way, and thus do not violate the DiD assumptions.

- Insert Table 2 here -

\subsection{Estimation Results}

\section{Linear Probability Model}

In a first step, I estimate a linear probability model (LPM) in order to find out whether the parents' naturalisation status correlates with the probability of being on the high education track. ${ }^{15}$ Results show a positive and significant correlation between the parents' naturalisation status and the children's education track (Table 3, row 1). Children whose parents have acquired German citizenship have a 15 percentage points higher probability of being on the high education track. Given that only $21 \%$ of children with non-naturalised parents are on the high education track, this change is equivalent to an increase of $71 \%$. The coefficient remains stable when further control variables are added. Besides parents' naturalisation status, their educational background also has a large influence on the child's probability of being on the high education track (Table A 3). Children of mothers (fathers)

\footnotetext{
${ }^{15}$ Probit models yield similar results. They are available upon request.
} 
with tertiary education have a 25 (26) percentage points higher probability of being on the high education track compared to children of parents without schooling or professional degree. This finding is in line with the literature on educational success among immigrants (e.g. Riphahn 2003, Meurs, Puhani and von Haaren 2016) and natives (e.g. Dustmann 2004). Furthermore, results indicate that the probability of being on the high education track is similar for all origin groups. The relation between age and high education track attendance is slightly u-shaped, which is in line with findings of Hillmert and Jacob (2010). At younger ages (11/12), many pupils start in the higher track, because it is the most favoured one. Then, however, the share of individuals on the higher track decreases until the age of 15 , because some pupils have to leave the higher track, as the school track is too demanding. At the age of 17 , the share increases again. After having completed the lower or medium track (after grade 10), pupils in Germany can switch to a higher track school (often to "specialised high track schools") in order to achieve a university entrance qualification (for an overview of the German schooling system, see Puhani and Weber 2007 or Puhani, Dustmann and Schönberg 2014).

When the correlation between the mother's naturalisation status and the children's probability of being on the high education track is estimated separately from the link between the father's naturalisation status and children's educational attainment, naturalisation coefficients are somewhat smaller and less significant compared to the joint estimation, this is especially true for the father's naturalisation status (Table A 4 and Table A 5).

- Insert Table 3 here -

\section{Difference-in-Differences:}

In the next step, I compare educational participation of children before and after the reform of parents with a duration of residence between 8 and 14 years and of parents with a longer duration of residence. Row 2 of Table 3 shows the estimates of the interaction of the treatment group and post-reform period. Children of parents with a duration of residence between 8 and 14 years have a similar probability of being on the high education track in the post-reform period compared to children of parents with a longer duration in the pre-reform period. Although the coefficient of the DiD estimator is positive, its magnitude is much smaller compared to the coefficient of parents' naturalisation status in the LPM and insignificant. On the one hand, this result may indicate that parents' naturalisation status does not affect children's educational outcomes, and that the observed correlation in the 
LPM is due to self-selection with respect to unobservable characteristics. On the other hand, coefficients may not be significant because they are imprecisely estimated due to the small sample size. The coefficients of the additional control variables (Table A 6) are similar to those of the LPM estimations. Estimating the effect of parent's naturalisation status separately for mothers' and father's shows that the DiD estimator for mother's is smaller than the estimator for both parents (Table A 4). In contrast to this, the DiD estimator of the father's naturalisation status is larger and even weakly significant in specifications five and six (Table A 5).

In addition, I use native children as an alternative control group. Since their parents' citizenship status is always German, they were not affected by the reform. The DiD estimator is negative and small in the specifications one and two and positive in specifications three to six but only weakly significant in the last specification (Table A 7). Although this approach controls for time-specific effects that affect both groups, for example a general positive time trend in educational attainment, native children may not be an adequate control group, because other time trends may affect educational outcomes of native and immigrant children differently. For example, increasing awareness of the necessity for integration of immigrants and catering to their special needs may improve educational attainment of immigrant children, but does not affect natives. In that case, the DiD assumptions would be violated.

\section{Instrumental Variable Approach}

While DiD models estimate intention-to-treat effects, the first stage of the IV approach takes into account whether individuals in fact react to the reform. The first stage estimates show that the instrument, the interaction of the treatment group and the post-reform period, increases the parents' naturalisation probability significantly. Controlling for children's demographic characteristics, parents of the treatment group have a 5 percentage points higher probability of naturalisation after the reform compared to parents of the control group in the pre-reform period (Table 3, row 3). However, when the parents' educational background is held constant, the first stage is not significant anymore. This is problematic, as it may indicate that the exclusion restriction is not fulfilled. Furthermore, the F-value, which is nearly 14 in the specification without further control variables, decreases to 3 or 2 when further explanatory variables are included. According to Staiger and Stock (1997), the F-value should be at least 10 , as a rule of thumb, otherwise the instrument may be weak. Therefore, although descriptive statistics show that naturalisation rates of affected parents 
increase after the reform (Figure 3), the instrument is not strong enough. Reasons for this may be that the increase of 7 percentage points is not large enough or that only a selective group of affected immigrants reacted to the reform. Consequently, the estimations here likely suffer from the weak instrument problem, which leads to imprecise estimates of the second stage. Local average treatment effects estimated in the second stage are reported in the fourth row of Table 3. They are positive but not significant. Since the first stage estimates in specifications five and six are not significant, I would not expect an effect in the second stage. In specifications one to four, the second stage may not be significant either because the first stage may be insufficiently strong (small F-value) or because the sample size is not large enough. Nevertheless, coefficients of the second stage are larger compared to the ITT (row 2), because the first stage incorporates whether parents actually react to the reform. The results of the IV model using the mother's treatment status as instrument for the mother's naturalisation status are similar to the results instrumenting the naturalisation status of both parents (Table A 4). First stage estimates of the father's treatment status however, are larger and significant in each specification, also controlling for the parents' educational background. Nevertheless, the instrumented coefficients of the father's naturalisation status on the children's educational outcomes estimated in the second stage are not significant either (Table A 5). This indicates that the reform worked for fathers, though the father's naturalisation status does not seem to increase investments in children's human capital.

\section{Robustness Checks}

To test the robustness of the results, I estimate the models for the observation period 1994 to 1998 and 2001 to 2006, in order to rule out the possibility of results being biased due to special effects in the year directly before and after the reform came into effect (e.g. due to anticipation effects, uncertainty on the part of the immigrants or overload on the part of the authorities). The coefficients of the LPM are almost identical compared to the non-restricted sample and the DiD estimators are somewhat larger, but results are overall consistent (Table A 9). Parents' naturalisation status is significantly correlated with children's education track (LPM), while DiD models yield mainly insignificant results. However, the first stage of the IV approach is too weak when the years 1999 and 2000 are excluded, therefore the instrument (interaction of treatment group and post-reform period) is not valid.

Furthermore, I divide the sample into subsamples of younger and older individuals aged 11 to 17 and 18 to 23 (Table A 10). On the one hand, the coefficient may be larger for the 
younger age group, as parents' influence might be larger on younger children. On the other hand, the coefficient may be larger for the older age group, as the educational system may be more open for individuals between 18 and 23 (as described above). Results of the LPM seem to support the second hypothesis: the coefficient of parents' naturalisation status is larger in the group of adolescents aged 18 to 23 (+24 percentage points, significant to the $5 \%$ level) than the coefficient in the sample of younger children $(+12$ percentage points, significant to the $10 \%$ level). Coefficients of the DiD and IV approach remain insignificant.

As described in section 2, several Turkish immigrants in particular used the domestic clause to gain dual citizenship in the late 1990s. Since the domestic clause was dropped in the law of 2000, the reform may not be regarded as facilitating for Turkish immigrants. Therefore, IV results may be biased for them and the coefficient of the total sample may be underestimated. However, Figure A 2 shows that naturalisation rates of mothers and fathers with Turkish origin where higher in the post-reform period than in the pre-reform period. Furthermore, Table A 11 presents estimation results based on a sample excluding immigrants from Turkey (column one to three) and based on a sample of immigrants from Turkey only (column four to six). In the sample excluding immigrants from Turkey the coefficient of the instrument on parents' naturalisation status is significant in the first stage (row three). However, the F-value remains small and the instrumented naturalisation coefficient in the second stage remains insignificant. In contrast, the first stage is not significant among immigrants from Turkey. However, when only the father's naturalisation status of children with Turkish origin is instrumented, the first stage is positive (+16 pp.) and significant to the 5\% level. It seems therefore, as if Turkish fathers reacted more strongly to the reform than Turkish mothers ${ }^{16}$, but the father's naturalisation status does not increase investments in children's human capital for immigrants from Turkey. In addition, Table A 11 shows the estimation results of the LPM and DiD models according to sample. The coefficient of parents' naturalisation status obtained from LPM is nearly identical for both samples $(+16$ percentage points compared to 15 percentage points), though the coefficient obtained in the sample excluding immigrants from Turkey is not significant any more (Table A 11, row one). The DiD estimators are different, but insignificant in both samples. While the share of children on the high education track increased over time among children without Turkish origin, it decreased for children with Turkish origin. Overall, these results show that children

\footnotetext{
${ }^{16}$ Although the naturalisation rates of Turkish mothers increased in the treatment group, they increased even more among Turkish mothers in the control group (Figure A 2).
} 
with Turkish and non-Turkish origin are different with respect to their educational attainment. Nevertheless, since naturalisation rates of Turkish immigrants increased (Figure A 1 and Figure A 2), the drop of the domestic clause did not seem to prevent Turkish immigrants from naturalisation. The reform worked at least for fathers with Turkish origin, as the first stage results of the IV estimation show.

As the reform increased the acceptance of multiple citizenship (von Münch 2007, see section 2 ), the question arises as to whether multiple citizenship of the parents has a different effect on their children's educational attainment. On the one hand the effect may be similar, but on the other hand individuals who decide to keep their original citizenship may be uncertain about their return migration plans. Therefore, the effects on children's education may be different. ${ }^{17}$ Information on multiple citizenships is only available since the year 2000 . In the sample analysed, $12 \%$ of naturalised mothers and $16 \%$ of naturalised fathers have a second citizenship. To check the robustness of the results, I exclude parents with multiple citizenship from the analyses. The coefficient of parents' naturalisation status increases from 14 to 16 percentage points and stays significant to the 5\% level. Results obtained from DiD and IV models stay insignificant (Table A 12). Results thus remain robust when parents with dual citizenship are excluded.

It is possible that the parents' naturalisation status has a stronger effect on the transition between low and medium education than between medium and high education. Therefore, I additionally analyse whether individuals whose parents are naturalised have a higher probability of undertaking or having completed an apprenticeship or being on the medium or high education track. In the German labour market, having completed an apprenticeship is the relevant requirement for working in qualified jobs. Therefore, this outcome variable also serves as an important measurement for investments in human capital. I compare individuals who are undertaking or have completed an apprenticeship or are on the medium or high education track to individuals who are in lower track schools, are doing vocational preparation in school or are unemployed. The results are robust. Children of naturalised parents have a 10 percentage points higher probability of undertaking an apprenticeship or

\footnotetext{
${ }^{17}$ However, keeping the original citizenship is only an endogenous decision for immigrants from EU member countries. Immigrants from remaining countries are only allowed to keep their original citizenship if giving up their original citizenship is impossible e.g. if they are recognised refugees (Bundesregierung n.d. a), see also section 2).
} 
being on the medium or high education track than children of non-naturalised parents (Table A 13). Results of the DiD and the IV estimations are not significant.

\section{Discussion of Possible Channels}

The hypothesis as to why naturalisation may increase parents' investments in their children's human capital is based on the idea that naturalisation ensures residence status and may induce parents to stay in Germany longer. Therefore, the expected returns of the investments are larger. Even though results suggest that parents' naturalisation status itself has no causal effect on children's educational outcomes, naturalised parents may be self-selected with respect to their return migration plans. This means that the longer time horizon of naturalised parents may still be a reason for higher investments, although it is an endogenous decision. According to this argumentation, parents' willingness to naturalise and their willingness to stay in Germany may themselves have a positive effect on investments in their children's human capital. To test this hypothesis, I run regressions with dummy variables either for (i) parents planning to naturalise within the next two years, (ii) parents wishing to stay forever in Germany or (iii) parents planning to stay for at least ten more years in Germany as explanatory variables instead of parents' naturalisation status. While realised naturalisation of the parents is significantly positively correlated to their children's educational participation, there is a negative correlation between parents who state that they plan to apply for German citizenship within the next two years and their children's education (Table A 14). This difference may be due to differences in revealed and stated preferences. Another possible explanation may be that individuals who state that they plan to naturalise may want to naturalise but do not fulfil the requirements, and are thus negatively self-selected. Descriptive statistics support this supposition: the share of lowly educated and non-working parents is higher among those who plan to naturalise compared to those who are naturalised. Nevertheless, planning to naturalise is still a valid indicator for naturalisation in the future, as most parents who are naturalised said two years before naturalisation that it is very likely that they will apply for German citizenship within the next two years (84\% of mothers and $75 \%$ of fathers). Furthermore, Table A 14 shows that the time horizon concerning the residence in Germany does not seem to be correlated with the children's educational outcome. This implies that the hypothesis of naturalised parents investing more in their children's human capital because of higher returns due to a longer time horizon cannot be 
confirmed. On the one hand, this may indicate that the parents' naturalisation status still has an effect itself. On the other hand, this result may also reveal that naturalised parents differ in other unobserved characteristics from non-naturalised parents and that these characteristics also influence children's educational outcomes.

To shed more light on possible channels that may explain why children of naturalised parents have a higher probability of being on the high education track, I analyse additional outcome variables which are available for a subsample of 17-year-old respondents. These variables refer, firstly, to parents' investments in their children, namely whether children receive private paid tutoring and whether parents are strongly concerned about their children's schooling achievement. Secondly, individuals are also asked about their values, perceptions and aims. I use this information to examine whether children of naturalised and nonnaturalised parents have different attitudes concerning the importance of schooling degrees and career orientation. However, information from this additional youth questionnaire is available only since 2000. Therefore, the reform of the naturalisation law cannot be exploited to estimate the effect of parents' naturalisation status on theses outcomes. This part of the analysis is thus descriptive only. Results show that adolescents whose parents are naturalised receive private paid tutoring more often than adolescents whose parents are not naturalised (47\% versus $29 \%$, Table 4). Furthermore, $44 \%$ of adolescents with naturalised parents state that their parents are strongly or very strongly concerned about their schooling success, while only $26 \%$ of respondents with non-naturalised parents do. These differences stay significant (mainly to the $10 \%$ and $12 \%$ level) controlling for the parents' educational background and employment status as well as for the adolescents' origin and the actual schooling track (Table A 15). Comparing adolescents' attitudes according to parents' naturalisation status shows that the share of adolescents who think that the schooling degree is important for success in life is similar for both groups (67\% vs. 70\%, Table 4). However, more adolescents whose parents are naturalised state that high income, good promotion opportunities and high occupational prestige are important factors for their occupational choice (79\%) compared to adolescents whose parents are not naturalised (50\%). This difference remains large and strongly significant (to the 1\% level) in the multivariate LPM (Table A 15).

In summary, the analysis of these additional outcomes suggests that naturalised parents invest more in their children's education and that naturalised adolescents have different attitudes with respect to career orientation. These attitudes are probably influenced by their parents. Therefore, results indicate that education and occupational success has high priority 
for naturalised parents, which may be the reason why their children are more likely to be on the high education track.

- Insert Table 4 here -

\section{Conclusions}

This paper examines a policy measure that aimed to improve immigrants' integration, namely the introduction of the new citizenship law in the year 2000 in Germany. In particular I analyse whether naturalisation increases parents' investments in their children's human capital. Investments in human capital are approximated by being on the high education track. Human capital acquisition is essential for future labour market success and thus for labour market integration of immigrants overall.

Results of multivariate LPM show a strong and significant correlation between parents' naturalisation status and the probability of being on the high education track $(+15$ percentage points). Since naturalised parents may differ in unobservable characteristics from nonnaturalised parents, I exploit the exogenous variation in the required years of residence for naturalisation in the year 2000. Using a DiD design, I compare children of parents with a duration of residence between 8 and 14 years (treatment group) and children of parents with a duration of at least 15 years (control group) before and after the reform. The DiD estimator is insignificant, indicating that the descriptively observed positive correlation may be due to self-selection. Since the DiD approach estimates intention-to-treat effects, I additionally instrument parents' naturalisation status by the interaction of the treatment group and the post-reform period in order to incorporate whether individuals actually react to the reform. The first stage is only significant in some specifications and the F-value is small, indicating that the instrument may be weak. Consequently, the coefficient of the instrument obtained from the second stage is not significant either. All in all, results suggest that naturalised parents are a positively self-selected group.

Additional results for a subsample of 17-year-old respondents reveal that education and career have a high priority for naturalised parents and their children, which may be the reason why their children are more often on the high education track. Naturalised parents are more concerned about their children's schooling achievement, their children more often receive 
private paid tutoring than children of non-naturalised parents, and children of naturalised parents are more career-orientated.

Even though the study does not identify a causal effect of parents' naturalisation status on investments in children's human capital, I show that children of naturalised parents are more often on the high education track. Moreover, the study sheds some light on possible channels that may explain why this is the case. Consequently, results cannot corroborate the notion that facilitating naturalisation is an effective policy measure to improve immigrants' education, but the study nevertheless confirms that naturalisation serves as a good indicator for integration.

\section{Acknowledgments:}

I would like to thank Patrick A. Puhani, Stephan L. Thomsen and Malte Sandner for helpful comments as well as discussants at the Spring Meeting of Young Economists 2015 and the research seminar at the NIW Hannover. The data used in this paper were made available by the German Socio-Economic Panel Study (SOEP) at the German Institute for Economic Research (DIW), Berlin. 


\section{References}

Angrist, J. D., Imbens, G. W., and Rubin, D. B. (1996): Identification of causal effects using instrumental variables. Journal of the American Statistical Association, 91(434), 444-455.

Angrist, J. D., and Pischke, J. S. (2008): Mostly harmless econometrics: An empiricist's companion. Princeton university press.

Avitabile, C., Clots-Figueras, I. and Masella, P. (2013): The Effect of Birthright Citizenship on Parental Integration Outcomes. The Journal of Law and Economics, Vol. 56, No. 3, 777-810.

Becker, G. S. (1962): Investment in human capital: A theoretical analysis. The journal of political economy, 9-49.

Blundell, R., and Costa Dias, M. (2009): Alternative approaches to evaluation in empirical microeconomics. Journal of Human Resources, 44(3), 565-640.

Bundesregierung (1995): Bericht der Beauftragten der Bundesregierung für die Belange der Ausländer über die Lage der Ausländer in der Bundesrepublik Deutschland. Bonn.

Bundesregierung (2005): Bericht der Beauftragten der Bundesregierung für Migration, Flüchtlinge und Integration über die Lage der Ausländerinnen und Ausländer in Deutschland. Berlin.

Bundesregierung (n.d. a): Beauftragte für Migration, Flüchtlinge und Integration: Staatsangehörigkeit: Die Anspruchseinbürgerung: Ausnahmen (http://www.bundesregierung.de/Content/DE/StatischeSeiten/Breg/IB/Einbuergeru ng/ae-p-ausnahmen.html?nn=400114), accessed 28/02/2015.

Bundesregierung (n.d. b): Beauftragte für Migration, Flüchtlinge und Integration: Staatsangehörigkeit: Die Ermessenseinbürgerung (http://www.bundesregierung.de/Content/DE/StatischeSeiten/Breg/IB/Einbuergeru ng/ee-ermessenseinbuergerung.html), accessed 28/02/2015. 
Bundestagsdrucksache 16/9654 (2008): Bundestagsdrucksache 16/9654 vom 19.06.2008:

Klare Grenzen für die Rücknahme und den Verlust der deutschen Staatsangehörigkeit ziehen.

DIW (n.d.): SOEP Overview

(http://www.diw.de/en/diw_02.c.222508.en/soep_overview.html), accessed 04/02/2015.

Dustmann, C. (1999): Temporary Migration, Human Capital, and Language Fluency of Migrants. The Scandinavian Journal of Economics, Vol. 101, No. 2, 297-314.

Dustmann, C. (2004): Parental background, secondary school track choice, and wages. Oxford Economic Papers, Vol. 56, No 2, 209-230.

Dustmann, C., Frattini, T. and Lanzara, G. (2012): Educational achievement of secondgeneration immigrants: An international comparison. Economic Policy, 143-185.

Dustmann, C., Puhani, P. A., and Schönberg, U. (2014): The Long-Term Effects of Early Track Choice. IZA Discussion Paper No. 7897.

Frankfurter Allgemeine Zeitung (2005): Staatsangehörigkeit: 48.000 Türkischstämmige mit zwei Pässen

(http://www.faz.net/aktuell/politik/inland/staatsangehoerigkeit-48-000tuerkischstaemmige-mit-zwei-paessen-1210132.html), accessed 30/01/2015.

Felfe, C. and Saurer, J. (2014): Granting Birthright Citizenship - A Door Opener for Immigrant Children's Educational Participation and Success? CESIfo Working Paper No. 4959.

Gang, I. N. and Zimmermann, K. F. (2000): Is Child Like Parent? Educational Attainment and Ethnic Origin. Journal of Human Resources, 35 (3), 550-569.

Gathmann, C. and Keller, N. (2014): Returns to Citizenship? Evidence Germany's Recent Immigration Reforms, CESIfo Working Paper No. 4783.

Gnielinski, T. (1999): Die Reform des deutschen Staatsangehörigkeitsrechtes. Eine Analyse und Bewertung der vorliegenden Gesetzesvorhaben. Schriften zum Staatsund Völkerrecht, Vol. 83. 
Hailbronner, K. and Renner, G. (2005): Kommentar zum Staatsangehörigkeitsrecht. CH Beck, 4. revised edition.

Hillmert, S. and Jacob, M. (2010): Selections and social selectivity on the academic track: A life-course analysis of educational attainment in Germany, Research in Social Stratification and Mobility, Vol. 28, 59-76.

Krause, A., Rinne, U. Schüller, S. (2014): Kick It Like Özil? Decomposing the NativeMigrant Education Gap. International Migration Review, 1-33.

Meurs, D., Puhani P.A. and von Haaren, F. (2016): Number of Siblings and Educational Choices of Immigrant Children: Evidence from First- and Second-Generation Immigrants, Review of the Economics of the Household (forthcoming).

Mitrut, A., and Wolff, F. C. (2014): Investing in children's education: are Muslim immigrants different? Journal of Population Economics, 27(4), 999-1022.

Puhani, P.A. and Weber, A.M. (2007): Does the Early Bird Catch the Worm? Instrumental Variable Estimates of Early Educational Effects of Age of School Entry in Germany. Empirical Economics 32: 359-386.

Riphahn, R. T. (2003): Cohort effects in the educational attainment of second generation immigrants in Germany: an analysis of census data, Journal of Population Economics, 16(4), 711-737.

Sajons, C. (2015): Does Granting Citizenship to Immigrant Children Affect Family Return Migration? Journal of Population Economics, online first, doi 10.1007/s00148-0150573-9.

Schüller, S. (2015): Parental ethnic identity and educational attainment of secondgeneration immigrants. Journal of Population Economics, 28(4): 965-1004.

Staiger, D. and Stock, J. H. (1997): Instrumental Variables Regression with Weak Instruments. Econometrica, 65(3): 557-586.

Statistisches Bundesamt (2014): Bevölkerung und Erwerbstätigkeit: Bevölkerung mit Migrationshintergrund - Ergebnisse des Mikrozensus 2013. Fachserie 1, Reihe 2.2, Wiesbaden. 
Von Münch, I. (2007). Die deutsche Staatsangehörigkeit: Vergangenheit-GegenwartZukunft. Walter de Gruyter, Berlin.

Wagner, G. G., Frick, J. R., \& Schupp, J. (2007): The German Socio-Economic Panel study (SOEP)-evolution, scope and enhancements. Schmollers Jahrbuch 127(1), 139-169.

Worbs, S. (2008): Die Einbürgerung von Ausländern in Deutschland, Bundesamt für Migration und Flüchtlinge, Integrationsreport, Teil 3, Working Paper 17. 


\section{Tables}

Table 1: $\quad$ Number of Observations by Treatment and Control Group and Year

\begin{tabular}{lrl}
\hline Year & TG & CG \\
\hline 1994 & 3 & 421 \\
1995 & 7 & 382 \\
1996 & 5 & 349 \\
1997 & 8 & 285 \\
1998 & 15 & 244 \\
1999 & 8 & 206 \\
\hline 2000 & 77 & 221 \\
2001 & 35 & 210 \\
2002 & 38 & 184 \\
2003 & 38 & 174 \\
2004 & 25 & 171 \\
2005 & 21 & 159 \\
2006 & 19 & 154 \\
\hline Total & 299 & 3,160 \\
\hline
\end{tabular}

Source: SOEP v29 1994 to 2006, own calculations.

Table 2: $\quad$ Summary Statistics by Treatment and Control Group

\begin{tabular}{lrrrr}
\hline & \multicolumn{2}{c}{ Pre-reform (1994-1999) } & \multicolumn{2}{c}{ Post-reform (2000-2006) } \\
\hline & \multicolumn{1}{c}{ TG } & CG & TG & CG \\
\hline High education track & 0.26 & 0.21 & 0.31 & 0.21 \\
Parents naturalised & 0.00 & 0.02 & 0.11 & 0.07 \\
Age & 17.93 & 17.83 & 16.23 & 17.21 \\
Female & 0.61 & 0.46 & 0.50 & 0.48 \\
Mean number of siblings & 1.31 & 1.53 & 1.85 & 1.46 \\
Born in Germany & 0.02 & 0.86 & 0.13 & 0.92 \\
Western Europe & 0.26 & 0.34 & 0.07 & 0.28 \\
Eastern Europe & 0.28 & 0.24 & 0.60 & 0.15 \\
Turkey & 0.22 & 0.41 & 0.13 & 0.51 \\
Other countries & 0.24 & 0.00 & 0.20 & 0.05 \\
Mother's duration of residence & 9.67 & 23.45 & 11.38 & 25.46 \\
Father's duration of residence & 10.13 & 26.20 & 11.36 & 28.64 \\
Mother's education: low & 0.35 & 0.44 & 0.09 & 0.42 \\
Mother's education: medium & 0.37 & 0.51 & 0.71 & 0.50 \\
Mother's education: high & 0.28 & 0.05 & 0.19 & 0.08 \\
Father's education: low & 0.13 & 0.27 & 0.07 & 0.25 \\
Father's education: medium & 0.48 & 0.64 & 0.66 & 0.65 \\
Father's education: high & 0.39 & 0.09 & 0.27 & 0.10 \\
\hline Number of observations & 46 & 1,887 & 253 & 1,273 \\
\hline
\end{tabular}

Note: Due to missing information on parents' naturalisation status, the number of observations is lower for this variable (TG pre-reform: 38, post reform: 195; CG pre-reform: 1,807, post-reform: 1,169).

Source: SOEP v29, 1994-2006, own calculations. 
Table 3: Estimation Results of LPM, DiD and IV Models (Dependent Variable: Being on the High Education Track)

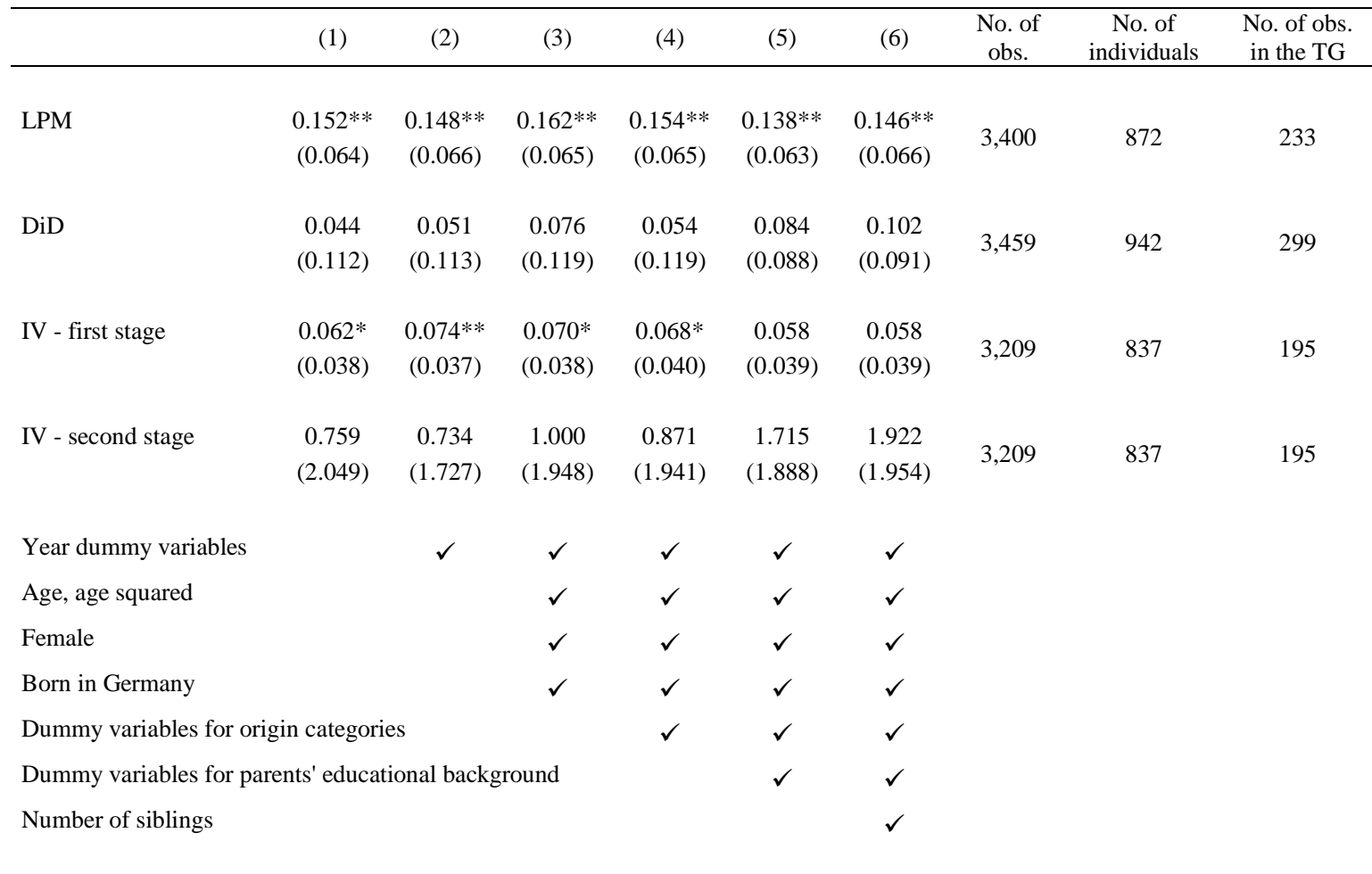

Note: The first row shows the coefficient of parents' naturalisation status on children's probability of being on the high education track obtained by LPM. The second row shows the coefficient of the DiD estimator (interaction of treatment group and post-reform period). The third row shows the first stage estimates of the IV approach, namely the coefficient of the interaction of treatment group and post-reform period on parents' probability of being naturalised. Row four shows results of the second stage. The sample is restricted to children aged between 11 and 23. Due to missing values in the variable "number of siblings", specification (6) is based on 3,216 (LPM), 3,271 (DiD), and 3,033 (IV) observations respectively. Reported standard errors in parentheses are robust and clustered by individual. * $(* * / * * *)$ denotes statistical significance at the $10 \%(5 \% / 1 \%)$ level.

Source: SOEP v29, 1994 to 2006, own calculations.

Table 4: Descriptive Statistics on Parents' Investments and Attitudes of 17-YearOlds

\begin{tabular}{|c|c|c|c|}
\hline & $\begin{array}{c}\text { Parents } \\
\text { non-naturalised }\end{array}$ & $\begin{array}{c}\text { Parents } \\
\text { naturalised }\end{array}$ & $\begin{array}{l}\text { Difference } \\
\text { significant }\end{array}$ \\
\hline Private paid tutoring & 28.5 & 46.9 & $* *$ \\
\hline Parents strongly concerned about their children's school achievement & 26.2 & 43.8 & $* *$ \\
\hline Schooling degree is important for success in life & 66.8 & 69.7 & \\
\hline Career chances are important criteria for occupational choice & 49.8 & 78.8 & $* * *$ \\
\hline Number of observations & 229 & 32 & \\
\hline
\end{tabular}

Note: The table shows descriptive shares for 17 -year-olds. * $(* * / * * *)$ denotes statistical significance at the $10 \%(5 \% / 1 \%)$ level.

Source: SOEP v29 2000 to 2012, own calculations 


\section{Figures}

Figure 1: Changes of the Required Years Since Migration (YSM) to Become Eligible for Naturalisation

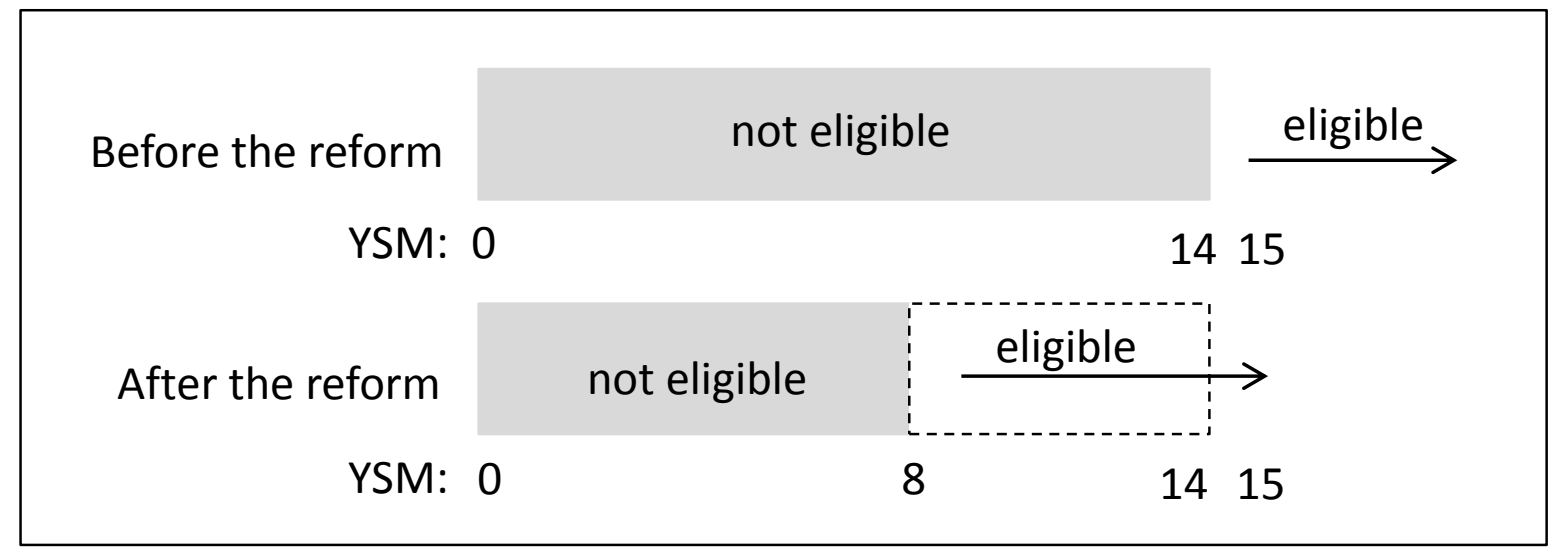

Note: The figure illustrates regulations for immigrants aged at least 23

Figure 2: Individuals Affected by the Reform

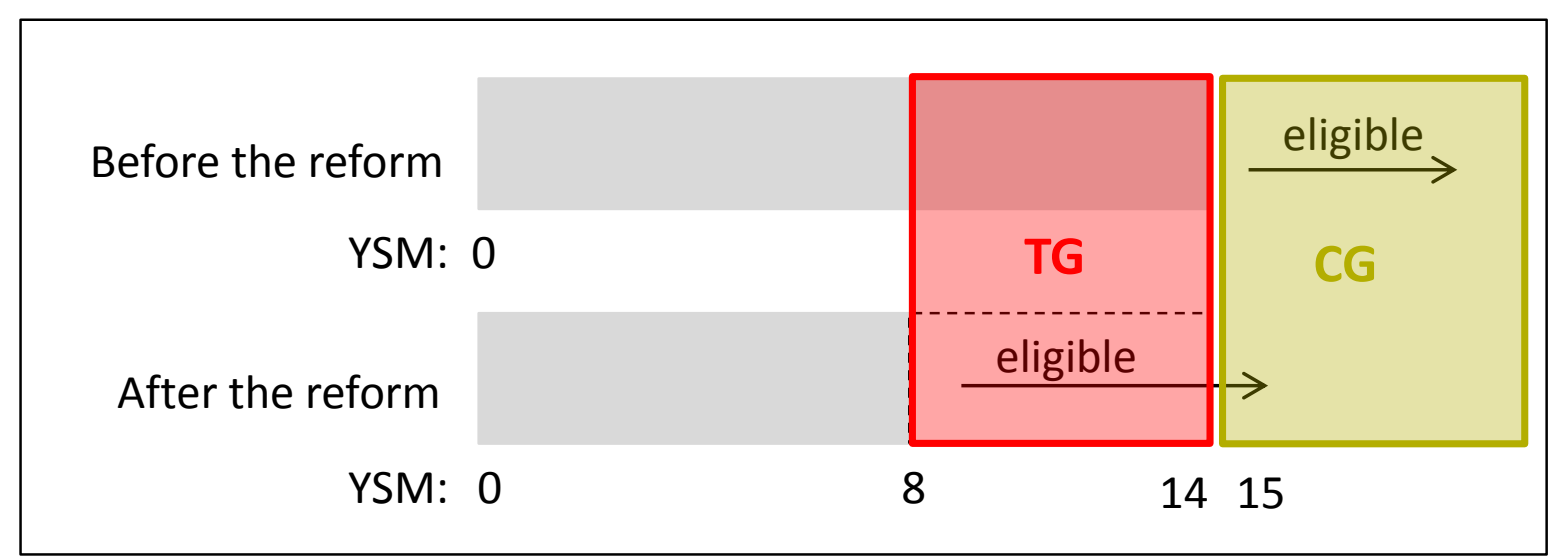


Figure 3: $\quad$ Share of Children with Naturalised Parents and Share of Children on the High Education Track in the Pre- and Post-Reform Period
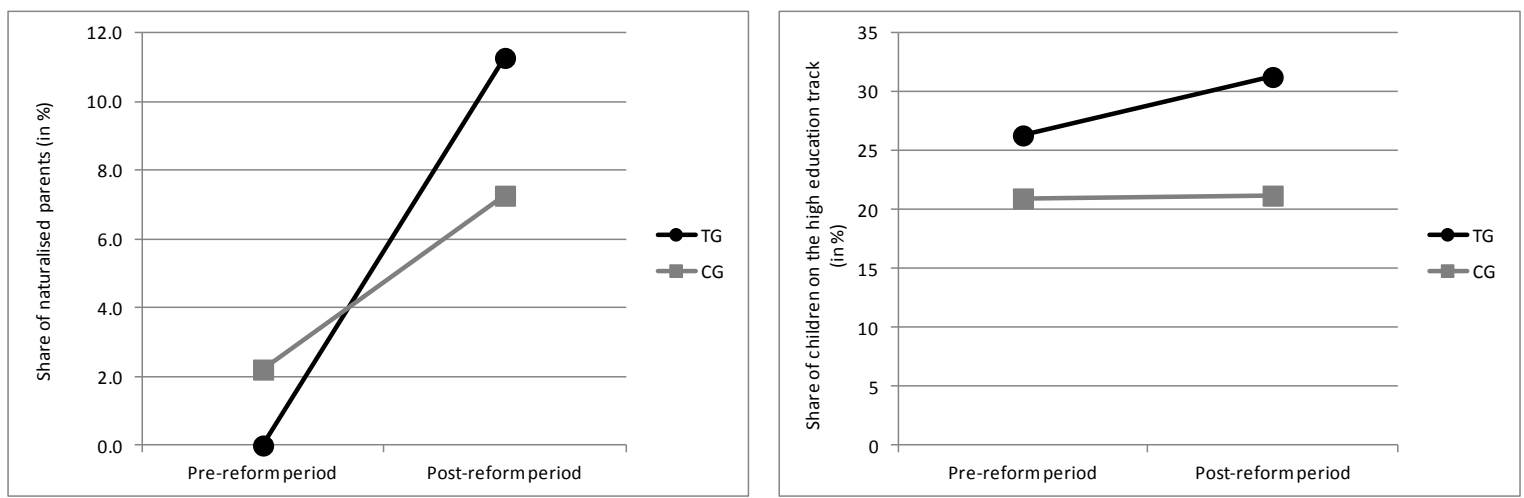

Note: In the pre-reform period, the number of observations is 38 in the treatment group and 1,807 in the control group. In the post-reform period, the number of observations is 195 in the treatment group and 1,169 in the control group. Source: SOEP v29, 1994-2006, own calculations. 


\section{Appendix}

\section{Tables}

\section{Table A 1 Overview of Naturalisation Regulations for Adults in Germany over Time}

\begin{tabular}{|c|c|c|c|c|c|}
\hline No claim & Principal claim & \multicolumn{4}{|c|}{ Legal claim } \\
\hline $\begin{array}{c}\text { Until } 1991 \\
\text { (§8 RuStAG) }\end{array}$ & $\begin{array}{c}1991 \\
(\S 85, \S 86 \text { AuslG) }\end{array}$ & $\begin{array}{c}1993 \\
(\S 85, \S 86 \text { AuslG) }\end{array}$ & $\begin{array}{c}2000 \\
\text { (until } 2004 \S 85, \S 86 \text { AuslG; } \\
\text { since } 2005 \S 10 \text { StAG) }\end{array}$ & 2005 & $2007 / 2008$ \\
\hline $\begin{array}{l}\text { - Naturalisation according } \\
\text { to the authority's } \\
\text { discretion }\end{array}$ & $\begin{array}{l}\text { - } 16 \text { to } 22 \text { years: residence } \\
\text { at least } 8 \text { years } \\
\text { - From } 23 \text { years: residence } \\
\text { at least } 15 \text { years } \\
\text { - Impunity } \\
\text { - Giving up former } \\
\text { citizenship } \\
\text { - Guarantee of subsistence } \\
\text { - Claim was restricted for } \\
\text { adults until } 31 / 12 / 1995\end{array}$ & $\begin{array}{l}\text { - } 16 \text { to } 22 \text { years: residence } \\
\text { at least } 8 \text { years } \\
\text { - From } 23 \text { years: residence } \\
\text { at least } 15 \text { years } \\
\text { - Impunity } \\
\text { - Giving up former } \\
\text { citizenship } \\
\text { - Guarantee of subsistence } \\
\text { - } 19 \text { to } 22 \text { years: } 6 \text { years of } \\
\text { schooling in Germany } \\
\text { - Fees: } 51 \text { Euro }\end{array}$ & $\begin{array}{l}\text { - Required years of residence: } 8 \text { years } \\
\text { (independently of age) } \\
\text { - Impunity } \\
\text { - Giving up former citizenship } \\
\text { - Guarantee of subsistence } \\
\text { - language proficiency } \\
\text { - confession to the free democratic } \\
\text { order of the German constitution } \\
\text { - increased acceptance of multiple } \\
\text { citizenship } \\
\text { - But: omission of the domestic clause } \\
\text { (,Inlandsklausel“) } \\
\text { - Fees: } 255 \text { Euro and } 51 \text { Euro for } \\
\text { under-age children }\end{array}$ & $\begin{array}{l}\text { Participation in an } \\
\text { integration course } \\
\text { reduces the required } \\
\text { years of residence from } 8 \\
\text { to } 7\end{array}$ & $\begin{array}{l}\text { - Additional requirement since 2007: } \\
\text { knowledge of legal and social } \\
\text { regulations and of living conditions in } \\
\text { Germany } \\
2008 \text { introduction of a naturalisation } \\
\text { test in order to prove knowledge of } \\
\text { legal and social regulations and of } \\
\text { living conditions in Germany }\end{array}$ \\
\hline
\end{tabular}

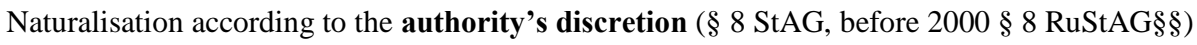

- No strict legal rules exist, but administrative regulations apply

- May be applied if one or more of the legal requirements is not fulfilled, especially for spouses and children of citizens or naturalised immigrants

- Administrative conditions:

- Duration of residence for spouses and under-age children: 4 years when they are co-naturalised or 3 years for spouses of German citizens

- Duration of residence for other individuals: usually 8 years since 2000; 10 years before 2000

- Duration of residence may be shorter if public interest exists (e.g. scientists, researchers, athletes)

- German language knowledge

Fees: before 1993 up to 2,556 Euro, but 75\% of monthly income at the maximum, since 1993255 Euro and 51 Euro for under-age children

Note: Before 2000 "naturalisation" of ethnic Germans was measured as "naturalisations due to legal claim”, since 2000 issuing a German passport for ethnic Germans is not regarded as naturalisation any more, because ethnic Germans are by definition Germans. New regulations for German-born children of immigrants are not described in the table. 
Table A 2: Share of Naturalised Mothers and Fathers by Treatment Status and Time (in \%)

\begin{tabular}{lcccc}
\hline & \multicolumn{2}{c}{ Pre-reform (1994-1999) } & \multicolumn{2}{c}{ Post-reform (2000-2006) } \\
\hline & TG & CG & TG & CG \\
\hline Mother naturalised & & & & 14.0 \\
Father naturalised & 0.0 & 2.9 & 15.5 & 9.5 \\
& 0.0 & 3.3 & & 9.8 \\
\hline
\end{tabular}

Note: The number of mothers in the treatment group is 404 and in the control group 3,150. The number of fathers in the treatment group is 315 and in the control group 3,249.

Source: SOEP v29, 1994 to 2006, own calculations.

Table A 3: Results of LPM (Dependent Variable: Being on the High Education Track)

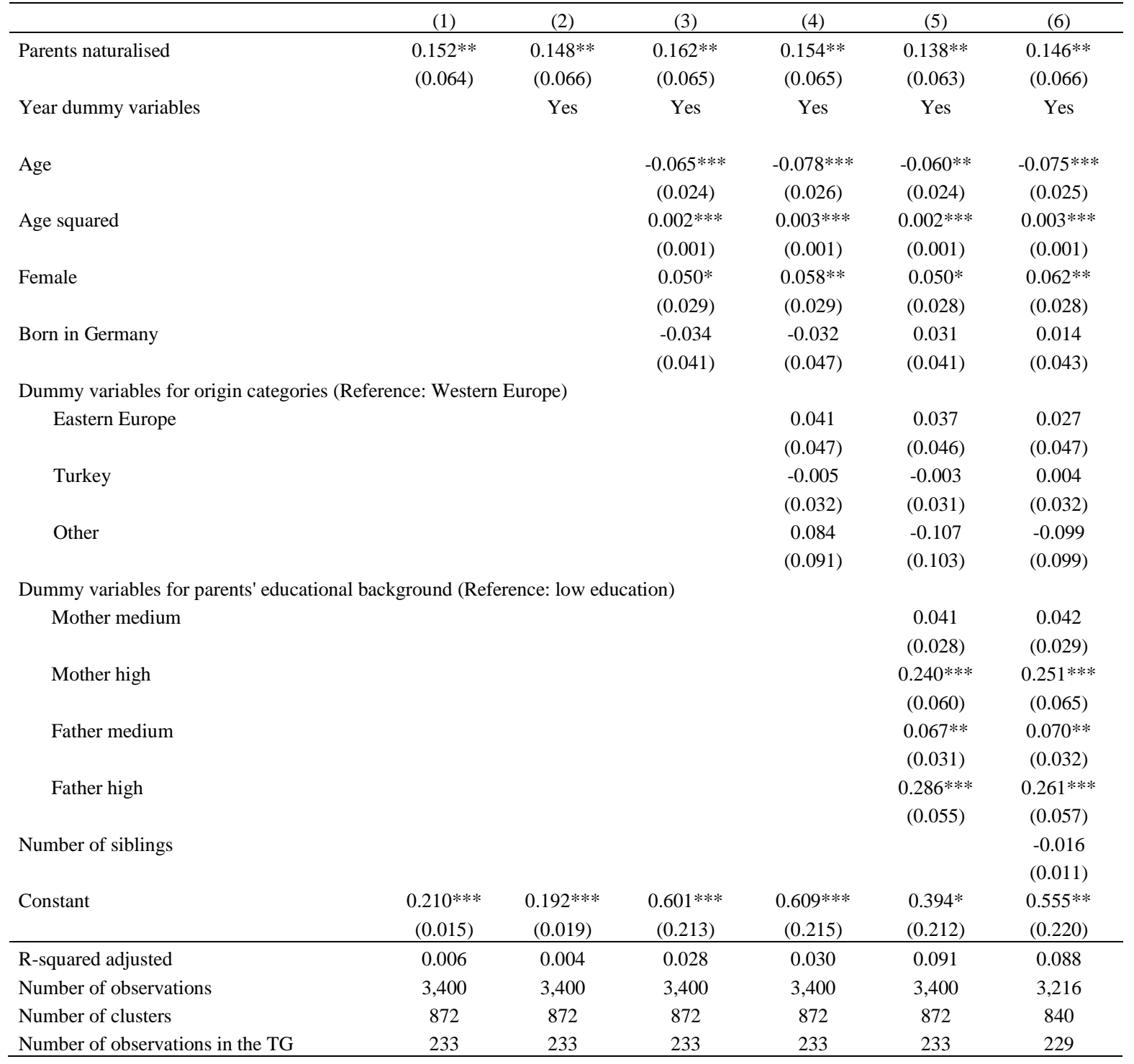

Note: Coefficients of linear probability models are displayed. The outcome variable is being on the high education track. The sample is restricted to individuals aged between 11 and 23 who are children of first-generation immigrants and whose parents have been living in Germany for at least 8 years. Reported standard errors in parentheses are robust and clustered by individual. * $(* * / * * *)$ denotes statistical significance at the $10 \%(5 \% / 1 \%)$ level.

Source: SOEP v29, 1994 to 2006, own calculations. 
Table A 4: Results of LPM, DiD and IV Models (Dependent Variable: Being on the High Education Track), Mother's Naturalisation / Treatment Status

\begin{tabular}{|c|c|c|c|c|c|c|c|c|c|}
\hline & (1) & (2) & (3) & (4) & (5) & (6) & $\begin{array}{c}\text { No. of } \\
\text { obs. }\end{array}$ & $\begin{array}{c}\text { No. of } \\
\text { individuals }\end{array}$ & $\begin{array}{l}\text { No. of obs. } \\
\text { in the TG }\end{array}$ \\
\hline LPM & $\begin{array}{c}0.107 * \\
(0.055)\end{array}$ & $\begin{array}{c}0.104 * \\
(0.056)\end{array}$ & $\begin{array}{c}0.115^{* *} * \\
(0.055)\end{array}$ & $\begin{array}{c}0.110^{*} \\
(0.056)\end{array}$ & $\begin{array}{c}0.093 * \\
(0.056)\end{array}$ & $\begin{array}{l}0.105 * \\
(0.059)\end{array}$ & 3,554 & 908 & 404 \\
\hline DiD & $\begin{array}{c}0.019 \\
(0.070)\end{array}$ & $\begin{array}{c}0.022 \\
(0.071)\end{array}$ & $\begin{array}{c}0.027 \\
(0.073)\end{array}$ & $\begin{array}{c}0.007 \\
(0.073)\end{array}$ & $\begin{array}{c}0.007 \\
(0.066)\end{array}$ & $\begin{array}{c}0.008 \\
(0.069)\end{array}$ & 3,795 & 1,009 & 472 \\
\hline IV - first stage & $\begin{array}{l}0.065^{*} \\
(0.033)\end{array}$ & $\begin{array}{c}0.072 * * \\
(0.033)\end{array}$ & $\begin{array}{c}0.075 * * \\
(0.033)\end{array}$ & $\begin{array}{c}0.051 \\
(0.033)\end{array}$ & $\begin{array}{c}0.045 \\
(0.032)\end{array}$ & $\begin{array}{l}0.056^{*} \\
(0.032)\end{array}$ & 3,554 & 908 & 285 \\
\hline IV - second stage & $\begin{array}{c}0.423 \\
(1.137)\end{array}$ & $\begin{array}{c}0.405 \\
(1.026)\end{array}$ & $\begin{array}{c}0.429 \\
(1.008)\end{array}$ & $\begin{array}{c}0.449 \\
(1.484)\end{array}$ & $\begin{array}{c}0.539 \\
(1.505)\end{array}$ & $\begin{array}{c}0.430 \\
(1.243)\end{array}$ & 3,554 & 908 & 285 \\
\hline
\end{tabular}

Year dummy variables

Age, age squared

Female

Born in Germany

Dummy variables for origin categories

Dummy variables for parents' educational background

Number of siblings

Note: The first row shows the coefficient of mothers' naturalisation status on children's probability of being on the high education track obtained by LPM. The second row shows the coefficient of the DiD estimator (interaction of treatment group and post-reform period). The third row shows the first stage estimates of the IV approach, namely the coefficient of the interaction of treatment group and post-reform period on parents' probability of being naturalised. Row four shows results of the second stage. The sample is restricted to children aged between 11 and 23. Due to missing values in the variable "number of siblings", specification (6) is based on 3,265 (LPM), 3,597 (DiD), and 3,365 (IV) observations respectively. Reported standard errors in parentheses are robust and clustered by individual. * $(* * / * * *)$ denotes statistical significance at the $10 \%(5 \% / 1 \%)$ level.

Source: SOEP v29, 1994 to 2006, own calculations. 
Table A 5: Results of LPM, DiD and IV Models (Dependent Variable: Being on the High Education Track), Father's Naturalisation / Treatment Status

\begin{tabular}{|c|c|c|c|c|c|c|c|c|c|}
\hline & (1) & (2) & (3) & (4) & (5) & (6) & $\begin{array}{c}\text { No. of } \\
\text { obs. }\end{array}$ & $\begin{array}{c}\text { No. of } \\
\text { individuals }\end{array}$ & $\begin{array}{l}\text { No. of obs. } \\
\text { in the TG }\end{array}$ \\
\hline LPM & $\begin{array}{c}0.113 * * \\
(0.056)\end{array}$ & $\begin{array}{l}0.111^{*} \\
(0.058)\end{array}$ & $\begin{array}{c}0.128 * * \\
(0.056)\end{array}$ & $\begin{array}{c}0.116^{* *} \\
(0.056)\end{array}$ & $\begin{array}{c}0.069 \\
(0.056)\end{array}$ & $\begin{array}{c}0.085 \\
(0.058)\end{array}$ & 3,579 & 911 & 270 \\
\hline DiD & $\begin{array}{c}0.107 \\
(0.094)\end{array}$ & $\begin{array}{c}0.113 \\
(0.094)\end{array}$ & $\begin{array}{c}0.135 \\
(0.099)\end{array}$ & $\begin{array}{c}0.115 \\
(0.100)\end{array}$ & $\begin{array}{c}0.134 * \\
(0.081)\end{array}$ & $\begin{array}{l}0.159 * \\
(0.084)\end{array}$ & 3,796 & 1,008 & 350 \\
\hline IV - first stage & $\begin{array}{c}0.090 * * \\
(0.036)\end{array}$ & $\begin{array}{c}0.098 * * * \\
(0.036)\end{array}$ & $\begin{array}{c}0.095 * * * \\
(0.036)\end{array}$ & $\begin{array}{c}0.083 * * \\
(0.038)\end{array}$ & $\begin{array}{c}0.085 * * \\
(0.039)\end{array}$ & $\begin{array}{c}0.087 * * \\
(0.039)\end{array}$ & 3,604 & 914 & 226 \\
\hline IV - second stage & $\begin{array}{c}1.222 \\
(1.240)\end{array}$ & $\begin{array}{c}1.168 \\
(1.140)\end{array}$ & $\begin{array}{c}1.353 \\
(1.243)\end{array}$ & $\begin{array}{c}1.352 \\
(1.397)\end{array}$ & $\begin{array}{c}1.577 \\
(1.274)\end{array}$ & $\begin{array}{c}1.801 \\
(1.300)\end{array}$ & 3,604 & 914 & 226 \\
\hline Age, age squared & & & $\checkmark$ & $\checkmark$ & $\checkmark$ & $\checkmark$ & & & \\
\hline Female & & & $\checkmark$ & $\checkmark$ & $\checkmark$ & $\checkmark$ & & & \\
\hline Born in Germany & & & $\checkmark$ & $\checkmark$ & $\checkmark$ & $\checkmark$ & & & \\
\hline Dummy variables for or & categorie & & & $\checkmark$ & $\checkmark$ & $\checkmark$ & & & \\
\hline \multicolumn{5}{|c|}{ Dummy variables for parents' educational background } & $\checkmark$ & $\checkmark$ & & & \\
\hline Number of siblings & & & & & & $\checkmark$ & & & \\
\hline
\end{tabular}

Note: The first row shows the coefficient of fathers' naturalisation status on children's probability of being on the high education track obtained by LPM. The second row shows the coefficient of the DiD estimator (interaction of treatment group and post-reform period). The third row shows the first stage estimates of the IV approach, namely the coefficient of the interaction of treatment group and post-reform period on parents' probability of being naturalised. Row four shows results of the second stage. The sample is restricted to children aged between 11 and 23. Due to missing values in the variable "number of siblings", specification (6) is based on 3,293 (LPM), 3,597 (DiD), and 3,416 (IV) observations respectively. Reported standard errors in parentheses are robust and clustered by individual. * $(* * / * * *)$ denotes statistical significance at the $10 \%(5 \% / 1 \%)$ level.

Source: SOEP v29, 1994 to 2006, own calculations. 
Table A 6: Results of the DiD Model (Dependent Variable: Being on the High Education Track)

\begin{tabular}{|c|c|c|c|c|c|c|}
\hline & $(1)$ & $(2)$ & (3) & (4) & $(5)$ & (6) \\
\hline TG*post-reform period & $\begin{array}{c}0.044 \\
(0.112)\end{array}$ & $\begin{array}{c}0.051 \\
(0.113)\end{array}$ & $\begin{array}{c}0.076 \\
(0.119)\end{array}$ & $\begin{array}{c}0.054 \\
(0.119)\end{array}$ & $\begin{array}{c}0.084 \\
(0.088)\end{array}$ & $\begin{array}{c}0.102 \\
(0.091)\end{array}$ \\
\hline TG & $\begin{array}{c}0.049 \\
(0.110)\end{array}$ & $\begin{array}{c}0.043 \\
(0.111)\end{array}$ & $\begin{array}{c}0.039 \\
(0.118)\end{array}$ & $\begin{array}{c}0.059 \\
(0.124)\end{array}$ & $\begin{array}{l}-0.008 \\
(0.092)\end{array}$ & $\begin{array}{l}-0.018 \\
(0.095)\end{array}$ \\
\hline Post-reform period & $\begin{array}{l}-0.001 \\
(0.025)\end{array}$ & $\begin{array}{c}0.060 \\
(0.038)\end{array}$ & $\begin{array}{l}0.073 * \\
(0.037)\end{array}$ & $\begin{array}{l}0.074 * \\
(0.038)\end{array}$ & $\begin{array}{c}0.042 \\
(0.037)\end{array}$ & $\begin{array}{c}0.033 \\
(0.038)\end{array}$ \\
\hline Year dummy variables & & Yes & Yes & Yes & Yes & Yes \\
\hline Age & & & $\begin{array}{c}-0.079 * * * \\
(0.025)\end{array}$ & $\begin{array}{c}-0.082^{* * *} * \\
(0.025)\end{array}$ & $\begin{array}{c}-0.072^{* * *} \\
(0.024)\end{array}$ & $\begin{array}{c}-0.083 * * * \\
(0.025)\end{array}$ \\
\hline Age squared & & & $\begin{array}{c}0.003 * * * \\
(0.001)\end{array}$ & $\begin{array}{c}0.003 * * * \\
(0.001)\end{array}$ & $\begin{array}{c}0.003 * * * \\
(0.001)\end{array}$ & $\begin{array}{c}0.003 * * * \\
(0.001)\end{array}$ \\
\hline Female & & & $\begin{array}{l}0.055^{*} \\
(0.028)\end{array}$ & $\begin{array}{l}0.054^{*} \\
(0.028)\end{array}$ & $\begin{array}{c}0.060 * * \\
(0.027)\end{array}$ & $\begin{array}{c}0.071 * * \\
(0.027)\end{array}$ \\
\hline Born in Germany & & & & $\begin{array}{c}0.020 \\
(0.046)\end{array}$ & $\begin{array}{c}0.045 \\
(0.041)\end{array}$ & $\begin{array}{c}0.036 \\
(0.043)\end{array}$ \\
\hline \multicolumn{7}{|c|}{ Dummy variables for origin categories (Reference: Western Europe) } \\
\hline Eastern Europe & & & & $\begin{array}{c}0.058 \\
(0.043)\end{array}$ & $\begin{array}{c}0.038 \\
(0.042)\end{array}$ & $\begin{array}{c}0.031 \\
(0.044)\end{array}$ \\
\hline Turkey & & & & $\begin{array}{c}0.020 \\
(0.033)\end{array}$ & $\begin{array}{c}0.021 \\
(0.032)\end{array}$ & $\begin{array}{c}0.027 \\
(0.032)\end{array}$ \\
\hline Other & & & & $\begin{array}{l}-0.003 \\
(0.067)\end{array}$ & $\begin{array}{c}-0.132 * \\
(0.071)\end{array}$ & $\begin{array}{c}-0.127 * \\
(0.069)\end{array}$ \\
\hline \multicolumn{7}{|c|}{ Dummy variables for parents' educational background (Reference: low education) } \\
\hline Mother medium & & & & & $\begin{array}{l}0.048 * \\
(0.027)\end{array}$ & $\begin{array}{c}0.046 \\
(0.028)\end{array}$ \\
\hline Mother high & & & & & $\begin{array}{c}0.237 * * * \\
(0.058)\end{array}$ & $\begin{array}{c}0.248 * * * \\
(0.064)\end{array}$ \\
\hline Father medium & & & & & $\begin{array}{c}0.075^{* *} \\
(0.030)\end{array}$ & $\begin{array}{c}0.080 * * * \\
(0.031)\end{array}$ \\
\hline Father high & & & & & $\begin{array}{c}0.278 * * * \\
(0.053)\end{array}$ & $\begin{array}{c}0.260 * * * \\
(0.055)\end{array}$ \\
\hline Number of siblings & & & & & & $\begin{array}{l}-0.017 \\
(0.011)\end{array}$ \\
\hline Constant & $\begin{array}{c}0.211^{* * * *} \\
(0.018)\end{array}$ & $\begin{array}{c}0.195 * * * \\
(0.019)\end{array}$ & $\begin{array}{c}0.683 * * * \\
(0.217)\end{array}$ & $\begin{array}{c}0.669 * * * \\
(0.228)\end{array}$ & $\begin{array}{c}0.458 * * \\
(0.223)\end{array}$ & $\begin{array}{c}0.575^{* *} \\
(0.231)\end{array}$ \\
\hline R-squared adjusted & 0.003 & 0.001 & 0.027 & 0.028 & 0.092 & 0.091 \\
\hline Number of observations & 3,459 & 3,459 & 3,459 & 3,459 & 3,459 & 3,271 \\
\hline Number of clusters & 942 & 942 & 942 & 942 & 942 & 908 \\
\hline Number of observations in the TG & 299 & 299 & 299 & 299 & 299 & 250 \\
\hline
\end{tabular}

Note: Coefficients of DiD models are displayed. The outcome variable is being on the high education track. The sample is restricted to children of first-generation immigrants aged between 11 and 23 . The treatment group consists of children whose parents were affected by the naturalisation reform in 2000: aged at least 23, foreign-born and with a duration of residence in Germany between 8 and 14 years. The control group consists of children from foreign-born individuals, aged at least 23 and with a duration of residence of at least 15 years. Reported standard errors in parentheses are robust and clustered by individual. * $(* * / * * *)$ denotes statistical significance at the $10 \%(5 \% / 1 \%)$ level.

Source: SOEP v29, 1994 to 2006, own calculations. 
Table A 7: Results of the DiD Model (Dependent Variable: Being on the High Education Track), Control Group: Native Children

\begin{tabular}{|c|c|c|c|c|c|c|}
\hline & $(1)$ & $(2)$ & (3) & (4) & $(5)$ & (6) \\
\hline TG*after & $\begin{array}{l}-0.029 \\
(0.110)\end{array}$ & $\begin{array}{l}-0.014 \\
(0.109)\end{array}$ & $\begin{array}{c}0.012 \\
(0.116)\end{array}$ & $\begin{array}{c}0.061 \\
(0.093)\end{array}$ & $\begin{array}{c}0.109 \\
(0.068)\end{array}$ & $\begin{array}{l}0.131 * \\
(0.070)\end{array}$ \\
\hline TG & $\begin{array}{l}-0.141 \\
(0.109)\end{array}$ & $\begin{array}{l}-0.142 \\
(0.109)\end{array}$ & $\begin{array}{l}-0.152 \\
(0.117)\end{array}$ & $\begin{array}{c}0.011 \\
(0.212)\end{array}$ & $\begin{array}{l}-0.003 \\
(0.120)\end{array}$ & $\begin{array}{l}-0.004 \\
(0.118)\end{array}$ \\
\hline After & $\begin{array}{c}0.072 * * * \\
(0.011)\end{array}$ & $\begin{array}{c}0.130 * * * \\
(0.017)\end{array}$ & $\begin{array}{c}0.132 * * * \\
(0.017)\end{array}$ & $\begin{array}{c}0.132 * * * \\
(0.017)\end{array}$ & $\begin{array}{c}0.082 * * * \\
(0.016)\end{array}$ & $\begin{array}{c}0.073 * * * \\
(0.016)\end{array}$ \\
\hline Year dummy variables & & Yes & Yes & Yes & Yes & Yes \\
\hline Age & & & $\begin{array}{c}-0.030 * * * \\
(0.011)\end{array}$ & $\begin{array}{c}-0.030 * * * \\
(0.011)\end{array}$ & $\begin{array}{c}-0.035^{* * *} \\
(0.010)\end{array}$ & $\begin{array}{c}-0.049 * * * \\
(0.011)\end{array}$ \\
\hline Age squared & & & $\begin{array}{c}0.001 * * * \\
(0.000)\end{array}$ & $\begin{array}{c}0.001 * * * \\
(0.000)\end{array}$ & $\begin{array}{c}0.001 * * * \\
0.000\end{array}$ & $\begin{array}{c}0.002 * * * \\
(0.000)\end{array}$ \\
\hline Female & & & $\begin{array}{c}0.097 * * * \\
(0.014)\end{array}$ & $\begin{array}{c}0.097 * * * \\
(0.014)\end{array}$ & $\begin{array}{c}0.092 * * * \\
0\end{array}$ & $\begin{array}{c}0.100 * * * \\
(0.013)\end{array}$ \\
\hline Born in Germany & & & $\begin{array}{l}-0.110 \\
(0.096)\end{array}$ & $\begin{array}{l}-0.109 \\
(0.097)\end{array}$ & $\begin{array}{l}-0.108 \\
(0.093)\end{array}$ & $\begin{array}{l}-0.105 \\
(0.095)\end{array}$ \\
\hline \multicolumn{7}{|c|}{ Dummy variables for origin categories (Reference: Western Europe) } \\
\hline Eastern Europe & & & & $\begin{array}{l}-0.241 \\
(0.192)\end{array}$ & $\begin{array}{c}-0.263 * \\
(0.136)\end{array}$ & $\begin{array}{c}-0.270 * \\
(0.138)\end{array}$ \\
\hline Turkey & & & & $\begin{array}{l}-0.212 \\
(0.233)\end{array}$ & $\begin{array}{l}-0.110 \\
(0.176)\end{array}$ & $\begin{array}{l}-0.080 \\
(0.179)\end{array}$ \\
\hline Other & & & & $\begin{array}{l}-0.202 \\
(0.197)\end{array}$ & $\begin{array}{c}-0.245^{*} \\
(0.140)\end{array}$ & $\begin{array}{c}-0.248 * \\
(0.142)\end{array}$ \\
\hline \multicolumn{7}{|c|}{ Dummy variables for parents' educational background (Reference: low education) } \\
\hline Mother medium & & & & & $\begin{array}{c}0.136^{* * *} \\
(0.022)\end{array}$ & $\begin{array}{c}0.142 * * * \\
(0.022)\end{array}$ \\
\hline Mother high & & & & & $\begin{array}{c}0.302 * * * \\
(0.026)\end{array}$ & $\begin{array}{c}0.304 * * * \\
(0.027)\end{array}$ \\
\hline Father medium & & & & & $\begin{array}{c}0.142 * * * \\
(0.025)\end{array}$ & $\begin{array}{c}0.141 * * * \\
(0.025)\end{array}$ \\
\hline Father high & & & & & $\begin{array}{c}0.478 * * * \\
(0.028)\end{array}$ & $\begin{array}{c}0.485^{* * * *} \\
(0.028)\end{array}$ \\
\hline Number of siblings & & & & & & $\begin{array}{c}-0.031 * * * \\
(0.007)\end{array}$ \\
\hline Constant & $\begin{array}{c}0.402 * * * \\
(0.011)\end{array}$ & $\begin{array}{c}0.389 * * * \\
(0.013)\end{array}$ & $\begin{array}{c}0.561 * * * \\
(0.093)\end{array}$ & $\begin{array}{c}0.559 * * * \\
(0.093)\end{array}$ & $\begin{array}{c}0.232 * * * \\
(0.089)\end{array}$ & $\begin{array}{c}0.370 * * * \\
(0.094)\end{array}$ \\
\hline R-squared adjusted & 0.006 & 0.009 & 0.020 & 0.020 & 0.188 & 0.195 \\
\hline Number of observations & 24,652 & 24,652 & 24,652 & 24,652 & 24,652 & 23,338 \\
\hline Number of clusters & 5,968 & 5,968 & 5,968 & 5,968 & 5,968 & 5,836 \\
\hline Number of observations in the TG & 299 & 299 & 299 & 299 & 299 & 250 \\
\hline
\end{tabular}

Note: Coefficients of DiD models are displayed. The outcome variable is being on the high education track. The sample is restricted to children aged between 11 and 23. The treatment group consists of children whose parents were affected by the naturalisation reform in 2000: aged at least 23, foreign-born and with a duration of residence in Germany between 8 and 14 years. The control group consists of children of natives. Reported standard errors in parentheses are robust and clustered by individual. $*(* * / * *)$ denotes statistical significance at the $10 \%(5 \% / 1 \%)$ level.

Source: SOEP v29, 1994 to 2006, own calculations. 
Table A 8: $\quad$ Results of the IV Model (Dependent Variable: Being on the High Education Track)

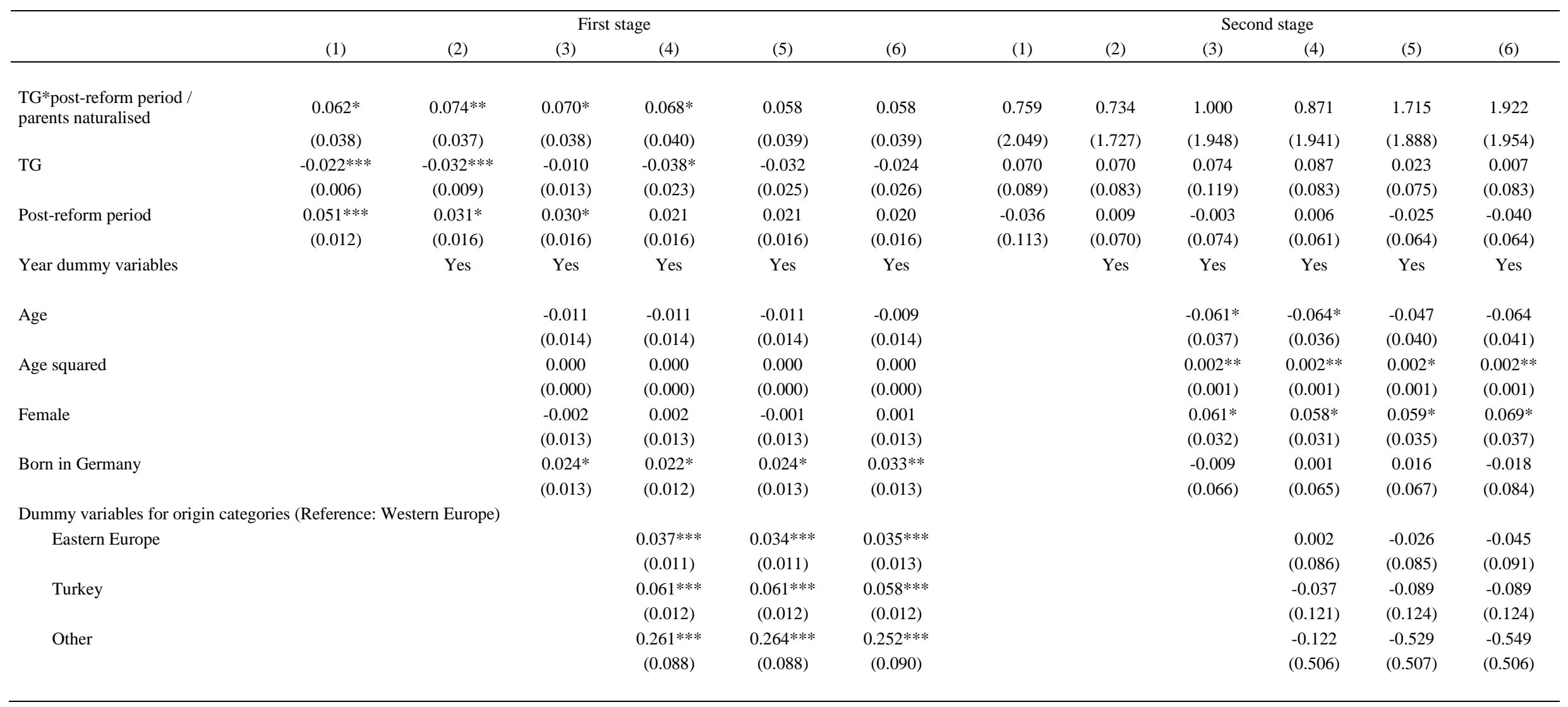




\section{Table A 8: Results of the IV Model (Dependent Variable: Being on the High Education Track) - continued}

\begin{tabular}{|c|c|c|c|c|c|c|c|c|c|c|c|c|}
\hline & \multicolumn{6}{|c|}{ First stage } & \multicolumn{6}{|c|}{ Second stage } \\
\hline & $(1)$ & (2) & (3) & (4) & (5) & (6) & (1) & (2) & (3) & (4) & (5) & (6) \\
\hline \multicolumn{13}{|c|}{ Dummy variables for parents' educational background (Reference: low education) } \\
\hline \multirow[t]{2}{*}{ Mother medium } & & & & & 0.019 & 0.023 & & & & & 0.013 & 0.002 \\
\hline & & & & & $(0.013)$ & $(0.015)$ & & & & & $(0.051)$ & $(0.062)$ \\
\hline \multirow[t]{2}{*}{ Mother high } & & & & & -0.014 & -0.016 & & & & & $0.258 * * *$ & $0.277 * * *$ \\
\hline & & & & & $(0.022)$ & $(0.025)$ & & & & & $(0.080)$ & $(0.091)$ \\
\hline \multirow[t]{2}{*}{ Father medium } & & & & & 0.016 & 0.016 & & & & & 0.044 & 0.046 \\
\hline & & & & & $(0.012)$ & $(0.013)$ & & & & & $(0.047)$ & $(0.049)$ \\
\hline \multirow[t]{2}{*}{ Father high } & & & & & 0.022 & 0.018 & & & & & $0.259^{* * *}$ & $0.240^{* * * *}$ \\
\hline & & & & & $(0.023)$ & $(0.024)$ & & & & & $(0.076)$ & $(0.078)$ \\
\hline \multirow{2}{*}{ Number of siblings } & & & & & & 0.007 & & & & & & -0.028 \\
\hline & & & & & & $(0.008)$ & & & & & & $(0.022)$ \\
\hline \multirow[t]{2}{*}{ Constant } & $0.022 * * *$ & $0.010^{* *}$ & 0.108 & 0.072 & 0.047 & 0.006 & $0.193 * * *$ & $0.181^{* * *}$ & 0.484 & $0.525^{*}$ & 0.316 & $0.528^{*}$ \\
\hline & $(0.006)$ & $(0.005)$ & $(0.115)$ & $(0.116)$ & $(0.118)$ & $(0.125)$ & $(0.047)$ & $(0.025)$ & $(0.332)$ & $(0.286)$ & $(0.307)$ & $(0.318)$ \\
\hline F-Value & 16.71 & 3.77 & 3.06 & 3.05 & 2.64 & 2.4 & & & & & & \\
\hline R-squared adjusted & 0.019 & 0.034 & 0.036 & 0.074 & 0.077 & 0.075 & - & - & - & - & - & - \\
\hline Number of observations & 3,209 & 3,209 & 3,209 & 3,209 & 3,209 & 3,033 & 3,209 & 3,209 & 3,209 & 3,209 & 3,209 & 3,033 \\
\hline Number of clusters & 837 & 837 & 837 & 837 & 837 & 808 & 837 & 837 & 837 & 837 & 837 & 808 \\
\hline Number of obs. in the TG & 195 & 195 & 195 & 195 & 195 & 192 & 195 & 195 & 195 & 195 & 195 & 192 \\
\hline
\end{tabular}

Note: The first panel shows the first stage estimates of the IV approach, namely the coefficient of the interaction of the treatment group and the post-reform period on parents' probability of being naturalised. The second panel shows results of the second stage, where being on the high education track is the dependent variable. The sample is restricted to children aged between 11 and 23. Reported standard errors in parenthesis are robust and clustered by individual. * $(* * / * * *)$ denotes statistical significance at the $10 \%(5 \% / 1 \%)$ level.

Source: SOEP v29, 1994 to 2006, own calculations. 
Table A 9: Robustness Check: Results for the Observation Period 1994 - 1998 / 2001 2006

\begin{tabular}{|c|c|c|c|c|c|c|c|c|}
\hline & (1) & (2) & (3) & (4) & (5) & (6) & No. of obs. & No. of cluster \\
\hline \multirow[t]{2}{*}{ LPM } & $0.146^{* *}$ & $0.143^{* *}$ & $0.161^{* *}$ & $0.154^{* *}$ & $0.141^{* *}$ & $0.145^{* *}$ & 2,777 & 820 \\
\hline & $(0.070)$ & $(0.072)$ & $(0.071)$ & $(0.072)$ & $(0.070)$ & $(0.070)$ & & \\
\hline \multirow[t]{2}{*}{$\mathrm{DiD}$} & 0.086 & 0.095 & 0.112 & 0.091 & 0.128 & $0.159^{*}$ & 2,947 & 877 \\
\hline & $(0.115)$ & $(0.115)$ & $(0.121)$ & $(0.123)$ & $(0.095)$ & $(0.096)$ & & \\
\hline \multirow[t]{2}{*}{ IV - first stage } & $0.074^{*}$ & $0.085^{*}$ & $0.081^{*}$ & $0.091^{*}$ & $0.082 *$ & $0.083^{*}$ & 2,773 & 818 \\
\hline & $(0.044)$ & $(0.044)$ & $(0.044)$ & $(0.048)$ & $(0.047)$ & $(0.046)$ & & \\
\hline \multirow[t]{2}{*}{ IV - second stage } & 1.183 & 1.132 & 1.289 & 1.051 & 1.731 & 2.009 & 2,773 & 818 \\
\hline & $(1.800)$ & $(1.560)$ & $(1.728)$ & $(1.478)$ & $(1.433)$ & $(1.487)$ & & \\
\hline \multicolumn{2}{|l|}{ Year dummy variables } & $\checkmark$ & $\checkmark$ & $\checkmark$ & $\checkmark$ & $\checkmark$ & & \\
\hline \multicolumn{3}{|l|}{ Age, age squared } & $\checkmark$ & $\checkmark$ & $\checkmark$ & $\checkmark$ & & \\
\hline \multicolumn{3}{|l|}{ Female } & $\checkmark$ & $\checkmark$ & $\checkmark$ & $\checkmark$ & & \\
\hline \multicolumn{3}{|l|}{ Born in Germany } & $\checkmark$ & $\checkmark$ & $\checkmark$ & $\checkmark$ & & \\
\hline \multicolumn{3}{|c|}{ Dummy variables for origin categories } & & $\checkmark$ & $\checkmark$ & $\checkmark$ & & \\
\hline \multicolumn{3}{|c|}{ Dummy variables for parents' educational background } & & & $\checkmark$ & $\checkmark$ & & \\
\hline \multicolumn{3}{|l|}{ Number of siblings } & & & & $\checkmark$ & & \\
\hline
\end{tabular}

Note: The first row shows the coefficient of parents' naturalisation status on children's probability of being on the high education track obtained by LPM. The second row shows the coefficient of the DiD estimator (interaction of treatment group and post-reform period). The third row shows the first stage estimates of the IV approach, namely the coefficient of the interaction of the treatment group and the post-reform period on parents' probability of being naturalised. Row four shows results of the second stage. The sample is restricted to children aged between 11 and 23. Due to missing values in the variable "number of siblings", specification (6) is based on 2,785 (DiD) and 2,621 (IV) observations respectively. Reported standard errors in parenthesis are robust and clustered by individual. * $(* * / * *)$ denotes statistical significance at the $10 \%(5 \% / 1 \%)$ level.

Source: SOEP v29, 1994-1998 and 2001-2006, own calculations. 
Table A 10: Robustness Check: Results for Different Age Groups

\begin{tabular}{|c|c|c|c|c|}
\hline & Age: & $11-23$ & $11-17$ & $18-23$ \\
\hline LPM & Parents naturalised & $\begin{array}{c}0.146 * * \\
(0.066)\end{array}$ & $\begin{array}{l}0.119^{*} \\
(0.068)\end{array}$ & $\begin{array}{c}0.242 * * \\
(0.120)\end{array}$ \\
\hline & $\begin{array}{l}\text { R-squared adjusted } \\
\text { No. of observations } \\
\text { No. of clusters }\end{array}$ & $\begin{array}{c}0.088 \\
3,216 \\
840\end{array}$ & $\begin{array}{c}0.090 \\
1,743 \\
561\end{array}$ & $\begin{array}{c}0.068 \\
1,473 \\
505\end{array}$ \\
\hline DiD & TG*After & $\begin{array}{c}0.102 \\
(0.091)\end{array}$ & $\begin{array}{c}0.033 \\
(0.115)\end{array}$ & $\begin{array}{c}0.120 \\
(0.124)\end{array}$ \\
\hline & $\begin{array}{l}\text { R-squared adjusted } \\
\text { No. of observations } \\
\text { No. of clusters }\end{array}$ & $\begin{array}{c}0.091 \\
3,271 \\
908\end{array}$ & $\begin{array}{c}0.087 \\
1,724 \\
598\end{array}$ & $\begin{array}{c}0.077 \\
1,547 \\
546\end{array}$ \\
\hline IV - First stage & TG*After & $\begin{array}{c}0.058 \\
(0.039)\end{array}$ & $\begin{array}{l}0.099 * \\
(0.055)\end{array}$ & $\begin{array}{l}-0.002 \\
(0.024)\end{array}$ \\
\hline & $\begin{array}{l}\text { R-squared adjusted } \\
\text { No. of observations } \\
\text { No. of clusters }\end{array}$ & $\begin{array}{c}0.075 \\
3,033 \\
808\end{array}$ & $\begin{array}{c}0.118 \\
1,585 \\
531\end{array}$ & $\begin{array}{c}0.029 \\
1,448 \\
497\end{array}$ \\
\hline IV-Second stage & Parents naturalised (instrumented) & $\begin{array}{c}1.922 \\
(1.954)\end{array}$ & $\begin{array}{c}0.525 \\
(1.154)\end{array}$ & $\begin{array}{c}-97.330 \\
(1365.290)\end{array}$ \\
\hline & $\begin{array}{l}\text { R-squared adjusted } \\
\text { No. of observations } \\
\text { No. of clusters }\end{array}$ & $\begin{array}{c}- \\
3,033 \\
808\end{array}$ & $\begin{array}{c}0.018 \\
1,585 \\
531\end{array}$ & $\begin{array}{c}- \\
1,448 \\
497\end{array}$ \\
\hline
\end{tabular}

Note: Column (1) shows estimation results for the full sample (individuals aged 11-23), column (2) shows results for the subsample of 11 to 17 -year-olds and column (3) for individuals aged 18 to 23 . The dependent variable is being on the high education track. The First stage of the IV estimation shows the coefficient of the interaction between treatment group and after the reform on the probability that parents are naturalised.

Source: SOEP v29, 1994 to 2006, own calculations. 


\section{Table A 11: Robustness Check: Results Based on a Sample of Immigrants with and without Turkish Origin}

\begin{tabular}{|c|c|c|c|c|c|c|}
\hline & \multicolumn{3}{|c|}{ Excluding immigrants from Turkey } & \multicolumn{3}{|c|}{ Immigrants from Turkey } \\
\hline & Coef. & No. of obs. & No. of cluster & Coef. & No. of obs. & No. of cluster \\
\hline \multicolumn{7}{|c|}{ Influence of both parents' naturalisation / treatment status } \\
\hline LPM & $\begin{array}{c}0.159 \\
(0.128)\end{array}$ & 1,720 & 455 & $\begin{array}{l}0.145^{*} \\
(0.076)\end{array}$ & 1,496 & 387 \\
\hline $\mathrm{DiD}$ & $\begin{array}{c}0.137 \\
(0.141)\end{array}$ & 1,875 & 540 & $\begin{array}{c}-0.202 \\
(0.154)\end{array}$ & 1,396 & 370 \\
\hline IV - first stage & $\begin{array}{l}0.075^{*} \\
(0.043)\end{array}$ & 1,649 & 447 & $\begin{array}{l}-0.047 \\
(0.032)\end{array}$ & 1,384 & 363 \\
\hline IV - second stage & $\begin{array}{c}1.874 \\
(2.149)\end{array}$ & 1,649 & 447 & $\begin{array}{c}4.181 \\
(4.962)\end{array}$ & 1,384 & 363 \\
\hline \multicolumn{7}{|c|}{ Influence of fathers' naturalisation / treatment status } \\
\hline LPM & $\begin{array}{c}0.157 \\
(0.104)\end{array}$ & 1,792 & 470 & $\begin{array}{c}0.102 \\
(0.065)\end{array}$ & 1,552 & 400 \\
\hline DiD & $\begin{array}{c}0.163 \\
(0.118)\end{array}$ & 2,034 & 568 & $\begin{array}{l}-0.033 \\
(0.175)\end{array}$ & 1,563 & 405 \\
\hline IV - first stage & $\begin{array}{c}0.045 \\
(0.042)\end{array}$ & 1,864 & 483 & $\begin{array}{c}0.159 * * \\
(0.075)\end{array}$ & 1,552 & 400 \\
\hline IV - second stage & $\begin{array}{c}3.084 \\
(2.878)\end{array}$ & 1,864 & 483 & $\begin{array}{c}-0.232 \\
(1.081)\end{array}$ & 1,552 & 400 \\
\hline
\end{tabular}

Note: The first row shows the coefficient of parents' naturalisation status on children's probability of being on the high education track obtained by LPM. The second row shows the coefficient of the DiD estimator (interaction of treatment group and post-reform period). The third row shows the first stage estimates of the IV approach, namely the coefficient of the interaction of the treatment group and the post-reform period on parents' probability of being naturalised. Row four shows results of the second stage. Row five to eight show the coefficient of fathers' naturalisation and treatment status. Further explanatory variables are year dummy variables, age, age squared, gender, being born in Germany, dummy variables for origin groups, parents' educational background and number of siblings. Reported standard errors in parenthesis are robust and clustered by individual. * $(* * / * *)$ denotes statistical significance at the $10 \% \quad(5 \% / 1 \%)$ level. Source: SOEP v29, 1994 to 2006, own calculations. 
Table A 12: Robustness Check: Results Based on a Sample Excluding Parents with Dual Citizenship

\begin{tabular}{|c|c|c|c|c|c|c|}
\hline & \multicolumn{3}{|c|}{ Total sample } & \multicolumn{3}{|c|}{ Excl. parents with second citizenship } \\
\hline & Coef. & No. of obs. & No. of cluster & Coef. & No. of obs. & No. of cluster \\
\hline IV - first stage & $\begin{array}{c}0.058 \\
(0.039)\end{array}$ & 3,033 & 808 & $\begin{array}{c}0.021 \\
(0.030)\end{array}$ & 3,011 & 803 \\
\hline IV - second stage & $\begin{array}{c}1.922 \\
(1.954)\end{array}$ & 3,033 & 808 & $\begin{array}{c}5.982 \\
(8.926)\end{array}$ & 3,011 & 803 \\
\hline
\end{tabular}

Note: The first row shows the coefficient of parents' naturalisation status on children's probability of being on the high education track obtained by LPM. The second row shows the coefficient of the DiD estimator (interaction of treatment group and post-reform period). The third row shows the first stage estimates of the IV approach, namely the coefficient of the interaction of the treatment group and the post-reform period on parents' probability of being naturalised. Row four shows results of the second stage. The results shown on column one to three are based on the total sample, the results in column four to six are based on a sample that excludes parents with second citizenship. Further explanatory variables are year dummy variables, age, age squared, gender, being born in Germany, dummy variables for origin groups, parents' educational background and number of siblings. Reported standard errors in parenthesis are robust and clustered by individual. ${ }^{*}(* * / * * *)$ denotes statistical significance at the $10 \%(5 \% / 1 \%)$ level.

Source: SOEP v29, 1994 to 2006, own calculations. 
Table A 13: $\quad$ Robustness Check (Dependent Variable: Undertaking or Having Completed an Apprenticeship or Being on the Medium or High Education Track)

\begin{tabular}{|c|c|c|c|c|}
\hline & \multirow{2}{*}{ LPM } & \multirow{2}{*}{$\mathrm{DiD}$} & \multicolumn{2}{|c|}{ IV } \\
\hline & & & First stage & Second stage \\
\hline \multirow[t]{2}{*}{ Parents naturalised } & $0.096^{*}$ & & & 0.880 \\
\hline & $(0.053)$ & & & $(1.727)$ \\
\hline \multirow[t]{2}{*}{ TG*after } & & 0.021 & 0.050 & \\
\hline & & $(0.081)$ & $(0.038)$ & \\
\hline \multirow[t]{2}{*}{ TG } & & 0.096 & -0.019 & 0.071 \\
\hline & & $(0.077)$ & $(0.025)$ & $(0.059)$ \\
\hline \multirow[t]{2}{*}{ After } & & -0.018 & 0.019 & -0.036 \\
\hline & & $(0.037)$ & $(0.016)$ & $(0.054)$ \\
\hline Year dummy variables & Yes & Yes & Yes & Yes \\
\hline \multirow[t]{2}{*}{ Age } & $0.047 *$ & $0.056^{* *}$ & -0.005 & $0.066^{* *}$ \\
\hline & $(0.026)$ & $(0.028)$ & $(0.015)$ & $(0.033)$ \\
\hline \multirow[t]{2}{*}{ Age squared } & 0.001 & 0.001 & 0.000 & 0.001 \\
\hline & $(0.001)$ & $(0.001)$ & $(0.000)$ & $(0.001)$ \\
\hline \multirow[t]{2}{*}{ Female } & $0.051 * *$ & $0.060 * * *$ & 0.001 & $0.058 * *$ \\
\hline & $(0.022)$ & $(0.023)$ & $(0.014)$ & $(0.026)$ \\
\hline \multirow[t]{2}{*}{ Born in Germany } & 0.029 & 0.046 & $0.034 * *$ & 0.024 \\
\hline & $(0.031)$ & $(0.035)$ & $(0.013)$ & $(0.071)$ \\
\hline \multicolumn{5}{|c|}{ Dummy variables for origin categories (Reference: Western Europe) } \\
\hline \multirow[t]{2}{*}{ Eastern Europe } & 0.023 & 0.018 & $0.037 * * *$ & -0.015 \\
\hline & $(0.033)$ & $(0.033)$ & $(0.013)$ & $(0.076)$ \\
\hline \multirow[t]{2}{*}{ Turkey } & $-0.065 * *$ & -0.035 & $0.061 * * *$ & -0.090 \\
\hline & $(0.027)$ & $(0.028)$ & $(0.013)$ & $(0.112)$ \\
\hline \multirow[t]{2}{*}{ Other } & $-0.155 * *$ & $-0.101 *$ & $0.254 * * *$ & -0.312 \\
\hline & $(0.067)$ & $(0.058)$ & $(0.090)$ & $(0.453)$ \\
\hline \multicolumn{5}{|c|}{ Dummy variables for parents' educational background (Reference: low education) } \\
\hline \multirow[t]{2}{*}{ Mother medium } & 0.034 & 0.034 & 0.025 & 0.006 \\
\hline & $(0.024)$ & $(0.025)$ & $(0.015)$ & $(0.053)$ \\
\hline \multirow[t]{2}{*}{ Mother high } & $0.169 * * *$ & $0.140 * * *$ & -0.015 & $0.163^{* *}$ \\
\hline & $(0.047)$ & $(0.047)$ & $(0.024)$ & $(0.065)$ \\
\hline \multirow[t]{2}{*}{ Father medium } & $0.045^{*}$ & $0.056 * *$ & 0.015 & 0.043 \\
\hline & $(0.027)$ & $(0.028)$ & $(0.013)$ & $(0.041)$ \\
\hline \multirow[t]{2}{*}{ Father high } & $0.182 * * *$ & $0.136^{* * * *}$ & 0.017 & $0.150 * *$ \\
\hline & $(0.047)$ & $(0.049)$ & $(0.024)$ & $(0.064)$ \\
\hline \multirow[t]{2}{*}{ Number of siblings } & -0.015 & $-0.024 * *$ & 0.006 & -0.025 \\
\hline & $(0.009)$ & $(0.010)$ & $(0.008)$ & $(0.016)$ \\
\hline \multirow[t]{2}{*}{ Constant } & $-0.663 * * *$ & $-0.777 * * *$ & -0.025 & $-0.814 * * *$ \\
\hline & $(0.220)$ & $(0.245)$ & $(0.128)$ & $(0.276)$ \\
\hline R-squared adjusted & 0.34 & 0.339 & 0.074 & 0.233 \\
\hline Number of observations & 3,623 & 3,353 & 3,111 & 3,111 \\
\hline Number of clusters & 927 & 910 & 810 & 810 \\
\hline
\end{tabular}

Note: Coefficients of a LPM, DiD model and second stage estimates of IV model are displayed. The outcome variable is undertaking or having completed an apprenticeship or being on the medium or high education track compared to being unemployed or being at a lower education track school. The sample is restricted to individuals aged between 17 and 23 who are children of first-generation immigrants who have lived in Germany for at least 8 years. Reported standard errors in parentheses are robust and clustered by individual. $*(* * / * * *)$ denotes statistical significance at the $10 \%(5 \% / 1 \%)$ level.

Source: SOEP v29, 1994 to 2006, own calculations. 
Table A 14: Results of LPM (Dependent Variable Being on the High Education Track), Alternative Explanatory Variables for Parents' Naturalisation Status

\section{(1)}

(2)

(3)

\author{
$0.127 * *$ \\ (0.064)
}

Parents plan to apply for citizenship

Parents wish to stay for ever in Germany

Parents plan to stay for at least 10 years in Germany

Year dummy variables

Age, age squared

Female

Born in Germany

Dummy variables for origin categories

Constant

ries

$-0.063^{* *}$

(0.028)

$-0.011$

(0.021)

\begin{tabular}{cccc} 
& & & -0.030 \\
$\checkmark$ & $\checkmark$ & $(0.026)$ \\
$\checkmark$ & $\checkmark$ & $\checkmark$ & $\checkmark$ \\
$\checkmark$ & $\checkmark$ & $\checkmark$ & $\checkmark$ \\
$\checkmark$ & $\checkmark$ & $\checkmark$ & $\checkmark$ \\
$\checkmark$ & $\checkmark$ & $\checkmark$ & $\checkmark$ \\
$0.465^{* *}$ & $0.535^{* * *}$ & $0.509 * *$ & $0.526^{* *}$ \\
$(0.204)$ & $(0.203)$ & $(0.204)$ & $(0.207)$ \\
& & & \\
\hline 0.096 & 0.097 & 0.093 & 0.094 \\
3,534 & 3,469 & 3,698 & 3,615 \\
925 & 911 & 1,041 & 1,026 \\
\hline
\end{tabular}

R-squared adjusted

Number of observations

Number of clusters

Note: Coefficients of linear probability models are displayed. The outcome variable is being on the high education track. The sample is restricted to individuals aged between 11 and 23 who are children of first-generation immigrants who have lived in Germany for at least 8 years. Reported standard errors in parentheses are robust and clustered by individual. * $(* * / * * *)$ denotes statistical significance at the $10 \%(5 \% / 1 \%)$ level.

Source: SOEP v29, 1994 to 2006, own calculations. 
Table A 15:

Results of LPM for 17-Year-Olds (Additional Dependent Variables

Dependent variable (1)

\author{
(2)
}

(3)

(4)

(5)

(6)

Dependent variable: Privately paid tutoring

Parents naturalised (coef.)

$0.191 *$

$0.202 *$

(0.102)

(0.104)

$0.172 *$

$0.212 * *$

$0.209 * *$

$0.193^{*}$

S.E.

0.013

0.011

0.116

(0.097)

(0.099)

(0.103)

R-squared adjusted

Dependent variable: Parents strongly concerned about their children's school achievement
Parents naturalised (coef.)
0.150
$0.151^{\mathrm{a}}$
$0.153^{\mathrm{a}}$
$0.172 *$
$0.161^{\mathrm{a}}$
$0.165^{\mathrm{a}}$
S.E.
(0.100)
(0.097)
(0.099)
(0.101)
(0.103)
(0.106)
R-squared adjusted
0.007
$-0.001$
0.018
0.014
0.006

Dependent variable: Schooling degree is important for success
Parents naturalised (coef.)
0.046
0.026
0.003
0.013
$-0.005$
$-0.014$
S.E.
(0.091)
(0.096)
(0.098)
(0.103)
(0.103)
(0.104)
R-squared adjusted
$-0.003$
0.002
0.007
0.039
0.045
0.042
Dependent variable: Career chances are important criteria for occupational choice
Parents naturalised (coef.)
$0.278 * * * \quad 0.278 * * *$
S.E.
(0.088) (0.090)
$0.255^{* * * *}$
$0.274 * * *$
$0.282 * * *$
$0.270 * * *$
R-squared adjusted
0.027
0.018
(0.093)
(0.096)
(0.097)
(0.094)
0.011
0.027
0.035

Dummy variables for parents' educational background

Dummy variables for origin categories

Born in Germany

Dummy variables for federal states

Dummy variables for type of schooling track

Dummy variables for parents' employment status

Number of observations

237

237

237

237

237

237

Note: The table displays coefficients of the explanatory variable "parents naturalised" for different dependent variables obtained from LPM. The sample consists of immigrant children aged 17 whose parents migrated to Germany. The observation period is 2000 to 2012 . Reported standard errors in parenthesis are robust. a $(/ * * * / * * *)$ denotes statistical significance at the $12 \%$ $(10 \% / 5 \% / 1 \%)$ level.

Source: SOEP v29, 2000 to 2012, own calculations. 


\section{Figures}

Figure A 1: Share of Naturalised Immigrants from Turkey and Remaining Countries by Year and Duration of Residence

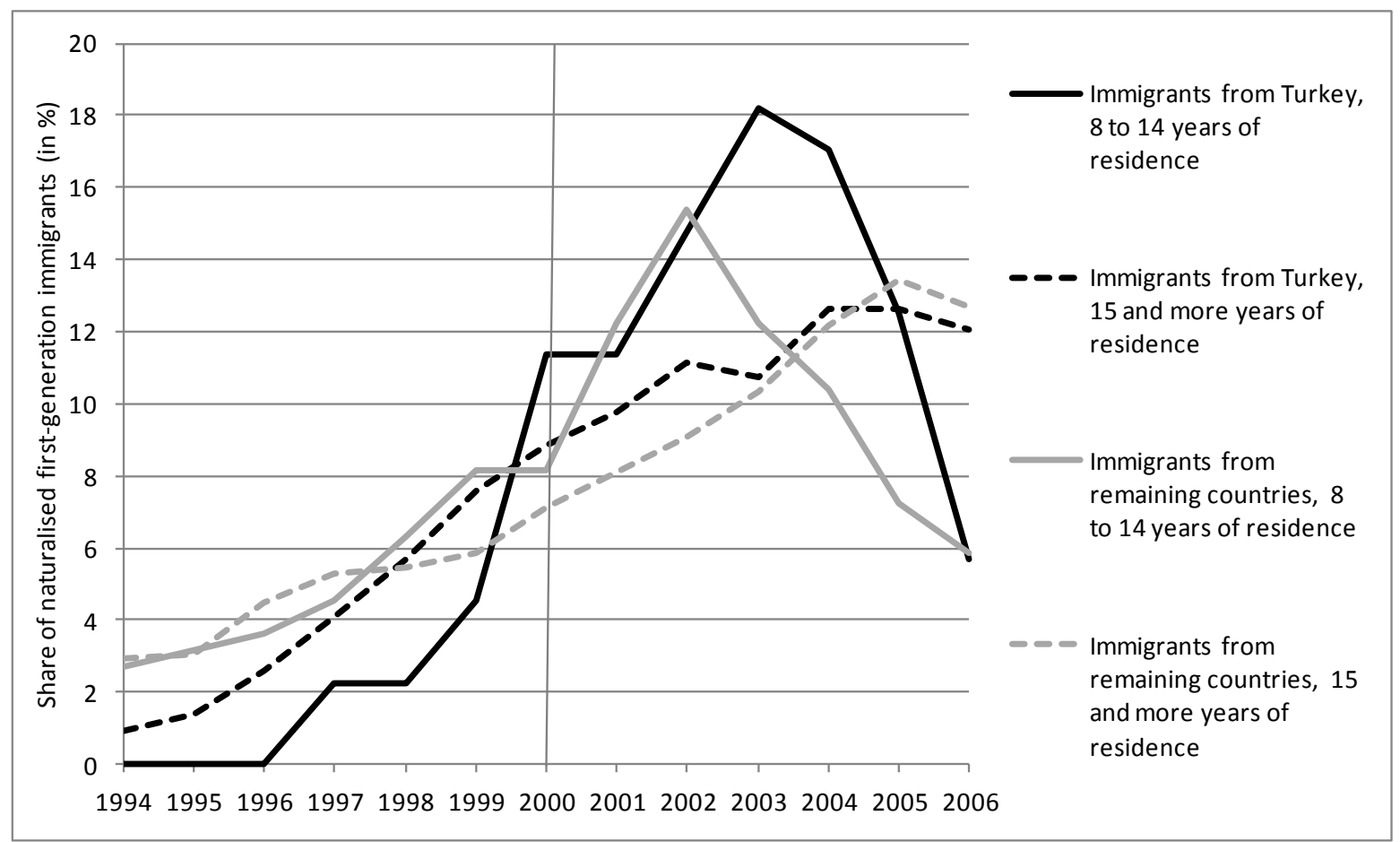

Note: In order to validate whether the reform affected immigrants from Turkey in general, the figure includes all first-generation immigrants, not only parents.

Source: SOEP v29, 1994 to 2006, all first-generation immigrants (excluding ethnic Germans), own calculations.

Figure A 2: Share of Children with Turkish Origin with Naturalised Mothers and Fathers according to Treatment Status in the Pre- and Post Reform Period
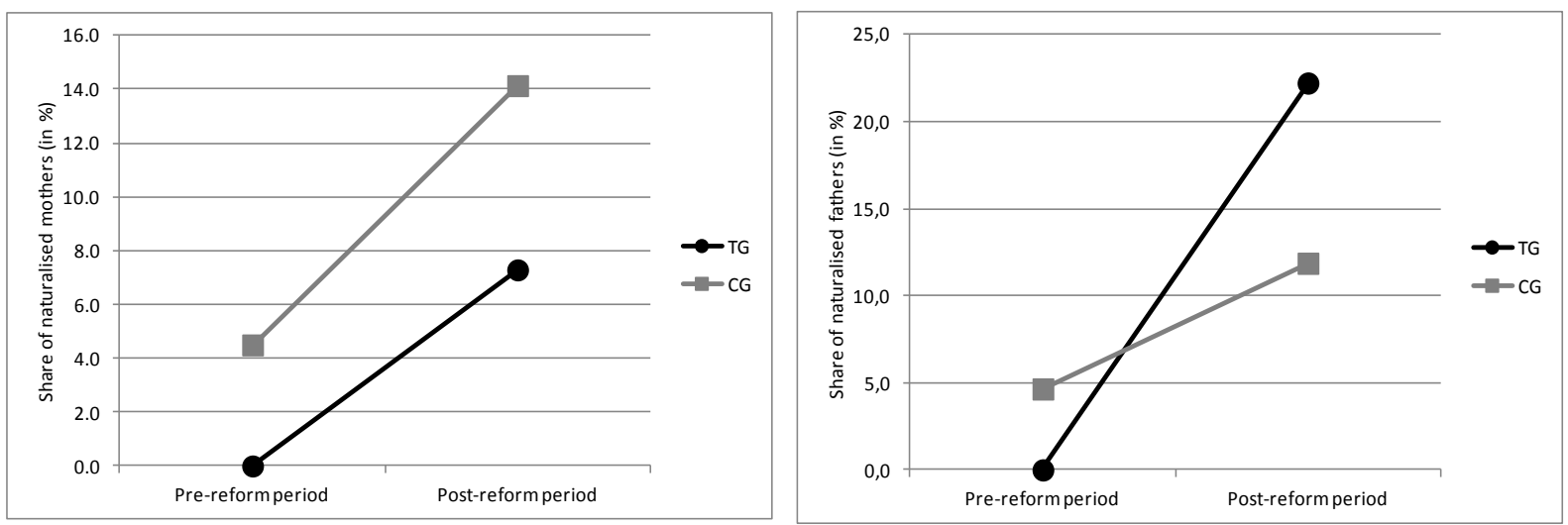

Note: In the pre-reform period, the number of observations is

41 for mothers in the treatment group (13 for fathers) and 800 mothers in the control group (839). In the post-reform period, the number of observations is 96 for mothers in the treatment group (54 fathers) and 679 mothers in the control group (733). Source: SOEP v29, 1994-2006, own calculations. 